\title{
State-of-the-Art Char Production with a Focus on Bark Feedstocks: Processes, Design, and Applications
}

\author{
Ali Umut Şen *(D) and Helena Pereira \\ CEF, Forest Research Centre, School of Agriculture, University of Lisbon, Tapada da Ajuda, \\ 1349-017 Lisbon, Portugal; hpereira@isa.ulisboa.pt \\ * Correspondence: umutsen@isa.ulisboa.pt
}

Citation: Şen, A.U.; Pereira, H.

State-of-the-Art Char Production with a Focus on Bark Feedstocks:

Processes, Design, and Applications.

Processes 2021, 9, 87. https://doi.org/ $10.3390 /$ pr9010087

Received: 2 December 2020

Accepted: 29 December 2020

Published: 2 January 2021

Publisher's Note: MDPI stays neutral with regard to jurisdictional clai$\mathrm{ms}$ in published maps and institutional affiliations.

Copyright: $\odot 2021$ by the authors. Licensee MDPI, Basel, Switzerland. This article is an open access article distributed under the terms and conditions of the Creative Commons Attribution (CC BY) license (https:// creativecommons.org/licenses/by/ $4.0 /)$.

\begin{abstract}
In recent years, there has been a surge of interest in char production from lignocellulosic biomass due to the fact of char's interesting technological properties. Global char production in 2019 reached 53.6 million tons. Barks are among the most important and understudied lignocellulosic feedstocks that have a large potential for exploitation, given bark global production which is estimated to be as high as 400 million cubic meters per year. Chars can be produced from barks; however, in order to obtain the desired char yields and for simulation of the pyrolysis process, it is important to understand the differences between barks and woods and other lignocellulosic materials in addition to selecting a proper thermochemical method for bark-based char production. In this state-of-theart review, after analyzing the main char production methods, barks were characterized for their chemical composition and compared with other important lignocellulosic materials. Following these steps, previous bark-based char production studies were analyzed, and different barks and process types were evaluated for the first time to guide future char production process designs based on bark feedstock. The dry and wet pyrolysis and gasification results of barks revealed that application of different particle sizes, heating rates, and solid residence times resulted in highly variable char yields between the temperature range of $220^{\circ} \mathrm{C}$ and $600{ }^{\circ} \mathrm{C}$. Bark-based char production should be primarily performed via a slow pyrolysis route, considering the superior surface properties of slow pyrolysis chars.
\end{abstract}

Keywords: bark; pyrolysis; charcoal; torrefaction; hydrothermal carbonization; gasification

\section{Introduction}

Biomass is defined by the Food and Agriculture Organization (FAO) as a biological material of non-fossilized origin [1]. The European Union classified biomass as the biodegradable fractions of products, wastes, and residues of biological origin from agriculture, forestry, and related industries including fisheries and aquaculture as well as the biodegradable fractions of industrial and municipal waste [2]. In spite of its very broad definition, which includes primary production and secondary sources, when the focus is on valorization and within a circular economy approach, biomass is considered to include five major classes of biological materials: agricultural wastes, forestry wastes, manure, microbial material, and organic wastes resulting from household and industrial processes [3]. Agricultural and forestry wastes, which share the common denominator of being lignocellulosic materials, are promising raw materials for biorefinery applications. The scope of this review is limited to agricultural and forestry wastes.

Tree barks are amongst the most important lignocellulosic biomass sources in the world. They make up approximately $10-20 \%$ of the stem volume and are present in roots, stumps, and branches [4,5]. A global bark production as high as 400 million cubic meters per year may be estimated based on FAO wood production figures [6]. Despite their abundance, tree barks are rarely used at a large scale, and most of the waste bark is either left in the forest or used for heating by local communities or as fuel in forest industries [7]. 
Only certain tree barks find industrial applications, for instance, the bark from Quercus suber is used for cork production and the bark from Picea abies for tannin production $[4,8]$. Several characteristics contribute to the underutilization of bark including the weaker mechanical properties, high ash content, low energy density, and high extractive contents as well as contaminations $[3,6,8]$. On the other side, barks have a complex structure and a rich and diverse chemistry that allow consideration of multiple and targeted applications, namely, within biorefineries [9]. In the last two decades, there has been large interest in the biorefineries concept for the valorization of lignocellulosic wastes, including tree barks, while the renewable energy policies enforced by various governmental agencies also induced a re-examination of the conventional conversion routes of lignocellulosic biomass [10-14].

Thermochemical conversion is a promising route for the valorization of waste biomass for the production of energy or value-added products [15]. The main thermochemical methods include combustion, pyrolysis, and gasification $[16,17]$. The selection of a particular thermochemical method largely depends on the desired target product type (i.e., char, liquid or gas) and chemical composition of the feedstock [17]. High carbohydrate and low-ash containing wood, energy crops, and agricultural wastes could be valorized via fast pyrolysis and gasification, because high yields of bio-oil or gas are likely to be obtained $[18,19]$. On the other hand, high-ash and low-carbohydrate containing lignocellulosic materials may be valorized through torrefaction, slow pyrolysis, and hydrothermal carbonization where the target product is char [20-22]. Intermediate pyrolysis may also be applied to lignocellulosic biomass to simultaneously obtain bio-oil and char at moderate yields $[16,23]$. Co-combustion of biomass with coal is also a possible conversion route to produce energy, although the co-combustion process is limited to low-ash containing biomass to avoid the slagging problem in the biomass furnace [24]. Biomass is often considered a carbon-neutral fuel, i.e., biomass burning does not increase the net greenhouse gas emissions, although it is likely that this is not fully correct as the $\mathrm{CO}_{2}$ emissions during combustion and time for the production of biomass are ignored [25-27]. However, co-combustion of biomass has also positive environmental effects such as the reduction of $\mathrm{SO}_{\mathrm{X}}$ and $\mathrm{NO}_{\mathrm{X}}$ emissions [28].

Barks maybe valorized through thermochemical conversion methods similar to other lignocellulosic wastes. However, for the development and simulation of a bark-based thermochemical process, several factors should be addressed, including the available data on previous studies, the effect of the bark chemical composition on the thermochemical products yields and compositions, properties and possible applications of the target products, and possibilities for developing an integrated biorefinery scheme.

Recently, there has been a growing interest and an extensive research on the fuel and non-fuel applications of lignocellulosic charcoals. Global charcoal production reached 53.6 million tons in 2019 according to FAO statistics with wood being the main biomass material for charcoal production. These data suggest that other lignocellulosic feedstocks, namely, under valorized materials, such as bark residues, may be processed to produce charcoals [29-34].

The objectives of this review were to present the current state of-the-art charcoal production methods and processes, to determine the current knowledge gaps, and to present a critical review for developing a feasible pyrolysis process using bark.

\section{An Overview of Thermal Conversion Processes}

The main thermal conversion methods may be classified as dry and wet pyrolysis (hydrothermal methods), gasification, and combustion methods (Table 1). Target materials or material groups are produced by these methods except in co-combustion of biomass with coal where the aim is to produce heat or electricity.

Dry pyrolysis is defined as a thermal destruction of organic matter either in the absence of an oxidizing agent (air or oxygen) or in isolated conditions with the presence of only a limited amount of oxidizing agent [35]. Pyrolysis is a traditional thermal process that has long been used by local communities to produce charcoal for different applications such as 
fuel, soil amender, adsorbent, etc. [36,37]. The terms char, charcoal, biocoal, coke or biochar describe the same dry pyrolysis product of biomass, but the usage of the material as fuel or in nonfuel applications determines its final name, e.g., biochar or biocoal are used for nonfuel chars, such as soil amendment chars, while coke and charcoal usually refer to fuel chars [38,39]. The production of bio-oils is also another possibility offered by dry pyrolysis. Bio-oils can be used as conventional fuels after upgrading or for the production of specialty or commodity chemicals $[16,18,40]$.

The temperature range in pyrolysis is usually between 300 and $550{ }^{\circ} \mathrm{C}$, but this range can be lower in torrefaction and higher in fast pyrolysis [16]. The mass yield and composition of the pyrolysis products depend on the feedstock properties (humidity, ash content, carbohydrate content, etc.) and the applied pyrolysis conditions (final temperature, heating rate, solid and vapor residence time, and pressure of the reaction) [41-43].

Hydrothermal carbonization and liquefaction methods are wet thermochemical methods where biomass is subjected to heat in the presence of water in its subcritical range to obtain a carbon-rich solid (hydrochar) and bio-oil (bio-crude), respectively [17,44].

Gasification is the thermal conversion of organic material at high temperature and under reducing conditions (either with sub-stoichiometric oxygen or without any added oxygen) to produce a gas mixture that can be used for heating, electricity generation or liquid fuels production [19].

Table 1. Main thermochemical processes.

\begin{tabular}{|c|c|c|c|c|c|c|c|c|}
\hline \multirow{2}{*}{$\begin{array}{l}\text { Thermochemical } \\
\text { Process }\end{array}$} & \multirow{2}{*}{$\begin{array}{c}\text { Final Tem- } \\
\text { perature } \\
\left({ }^{\circ} \mathrm{C}\right)\end{array}$} & \multirow{2}{*}{$\begin{array}{c}\text { Heating } \\
\text { Rate } \\
\left({ }^{\circ} \mathrm{C}_{\text {min }}^{-1}\right)\end{array}$} & \multirow{2}{*}{$\begin{array}{c}\text { Solid } \\
\text { Residence } \\
\text { Time (h) }\end{array}$} & \multirow{2}{*}{$\begin{array}{l}\text { Target } \\
\text { Products }\end{array}$} & \multicolumn{3}{|c|}{$\begin{array}{c}\text { Mass Balances } \\
(\%)\end{array}$} & \multirow{2}{*}{ Reference } \\
\hline & & & & & Char & Liquid & Gas & \\
\hline $\begin{array}{l}\text { Mild pyrolysis } \\
\text { (Torrefaction) }\end{array}$ & $200-300$ & $10-15$ & $0.5-4$ & $\begin{array}{l}\text { Torrefied } \\
\text { biomass }\end{array}$ & 70 & - & 30 & [17] \\
\hline Slow pyrolysis & $\begin{array}{l}300-650 \\
450-550\end{array}$ & $\begin{array}{c}10-30 \\
600-12000\end{array}$ & $\begin{array}{l}0.1-12 \\
<0.003\end{array}$ & Biochar & $\begin{array}{l}35 \\
12\end{array}$ & $\begin{array}{l}30 \\
75\end{array}$ & $\begin{array}{l}35 \\
13\end{array}$ & $\begin{array}{c}{[17,45]} \\
{[18,45,46]}\end{array}$ \\
\hline $\begin{array}{l}\text { Intermediate } \\
\text { pyrolysis }\end{array}$ & $350-500$ & 100 & $0.1-0.5$ & $\begin{array}{l}\text { Biochar } \\
\text { Bio-oil }\end{array}$ & 25 & 50 & 25 & {$[45,47,48]$} \\
\hline $\begin{array}{l}\text { Vacuum } \\
\text { pyrolysis }\end{array}$ & $300-600$ & 40 & $0.5-2$ & $\begin{array}{l}\text { Biochar } \\
\text { Bio-oil }\end{array}$ & 27 & 50 & 24 & [49-51] \\
\hline Gasification & $750-900$ & $3-900$ & $<0.003$ & Producer gas & 10 & 5 & 85 & {$[45,47,52,53]$} \\
\hline $\begin{array}{l}\text { Hydrothermal } \\
\text { carbonization }\end{array}$ & $180-260$ & $5-10$ & $0.1-12$ & Hydrochar & 60 & 30 & 10 & {$[17,54,55]$} \\
\hline $\begin{array}{l}\text { Hydrothermal } \\
\text { liquefaction }\end{array}$ & $260-374$ & $5-140$ & $0.01-0.7$ & Bio-oil & 25 & 60 & 15 & {$[17,44,56-60]$} \\
\hline
\end{tabular}

As can be seen from Table 1, the different thermochemical methods require a specific set of process conditions to maximize the target product (i.e., char, bio-oil, or gas) yields.

Chars have interesting technological properties such as reduced moisture, increased calorific value, increased surface area. These properties are strongly influenced by process types and conditions that determine the applications of the chars. In addition, similar char properties may be obtained by different pyrolysis methods. Thus, it is necessary to analyze these char production processes and applications of the produced chars.

\section{Main Char Production Processes and Applications of Chars}

\subsection{Mild Pyrolysis (Torrefaction)}

The pyrolysis reaction at mild conditions is also called torrefaction [61]. The process is performed at relatively low temperatures $\left(200-300^{\circ} \mathrm{C}\right)$ in comparison to other pyrolysis operations. The torrefaction reactions of lignocellulosic materials include mainly the decomposition of hemicelluloses and 70-90\% solid (char) yields are achieved [62]. The resulting char after torrefaction is usually called "torrefied matter" instead of "biochar" because it still contains volatile matter, although in reduced amount [17].

The torrefied matter has a higher energy density and a lower moisture content than the starting biomass [63-65], and it also has improved material properties such as reduced hydrophilicity and better grindability [62]. These properties suggest the utilization of torrefac- 
tion chars for energy purposes such as co-combustion with coal and gasification $[64,65]$. High-quality syngas can be produced from the gasification of torrefied matter because of the removal of the oxygenated compounds during torrefaction [20]. Torrefaction may be modified to obtain optimal conditions for heating value and energy yield [66]. The use of torrefaction severity index (TSI) or torrefaction severity factor (TSF) indices showed that the same degree of torrefaction can be achieved using a combination of high temperature and short residence times thereby allowing economic gains [67-69].

Wet torrefaction has the additional advantage of a reduced ash content in the torrefied matter, which may be important in producing fuels from high-ash containing biomass [70].

The use of torrefied matter for soil amendment is not common because of the toxic effect of the char. This toxicity arises from recondensation of pyrolysis vapors, particularly because of the low-molecular weight organic acids and phenols, which are claimed to be mobile and phytotoxic [71,72]. However, there are contradictory reports on the phytotoxicity of chars [73], which suggest that process conditions (temperature, removal of pyrolysis vapors) may play an important role in char properties and applications.

\subsection{Slow Pyrolysis}

Slow pyrolysis is carried out at higher temperatures and heating rates than those of torrefaction. Approximately $30 \%$ char yield is obtained [74]. The chemical composition of the feed material possibly plays an important role in the overall char yield in addition to the process conditions [75]. Higher ash and lignin contents of the feed material are likely to favor char formation [76]. The produced chars can be used as solid fuels or as soil amendment and C-sequestration material (biochar) [77]. The term biochar is defined as "charcoals that can be applied to soil for agricultural and environmental gains" by the International Biochar Initiative (IBI) [78]. A more specific definition of biochar is given by the European Biochar Foundation (EBF) which delimits the biochar production to a temperature range between $350^{\circ} \mathrm{C}$ and $1000^{\circ} \mathrm{C}$ [79]. Application of biochars is particularly promising because of the benefits in the soil such as improved water retention, reduced bulk density, increased cation exchange capacity (CEC), increased soil aeration, improved soil microbial ecology, increased soil surface area, increased nutrients retention, and increased stability $[74,78,80-83]$. Lignocellulosic biochars may also act as soil fertilizer since they contain four of the six plant macronutrients, i.e., $\mathrm{Ca}, \mathrm{K}, \mathrm{P}$, and $\mathrm{Mg}$ [84]. Biochar was also combined with mineral fertilizers prior to soil application and demonstrated positive results [85].

Biochar application also depends on soil type. Positive effects are usually observed with sandy soils, in contrast to loamy and clay soils for which improvement was not achieved $[81,86,87]$. Application of biochars may also lead to negative effects such as enrichment of trace elements, increased $\mathrm{pH}$ in soil, and formation of toxic and mobile aromatic compounds $[77,88]$. The increase in $\mathrm{pH}$ is related to the formation of basic cations, such as those derived from $\mathrm{CaCO}_{3}, \mathrm{SiO}_{2}$, and $\mathrm{KCl}[77,89,90]$, which is favorable at higher temperatures [91]. It has also been reported that formation of ethylene from biochars in soil inhibits soil microbial processes [92]. In practice, the high $\mathrm{pH}$ of biochars seems to be the main obstacle for soil application because most plants tend to grow best in slightly acidic soils [93]. However, the effect of biochar on soil fertility is not yet fully understood, and there are contradicting reports with increased or reduced crop yields after biochar application $[87,94]$. The increased $\mathrm{pH}$ of soil was also argued to increase crop yields $[95,96]$. It is likely that both biochar and soil properties determine the results of soil amendment application. The biochar properties are related to feedstock properties and pyrolysis conditions, and soil properties are related to soil type and properties, particularly soil biota $[95,96]$. An interesting side effect of soil amendments was the reduced leaching of the herbicide atrazine into biochar-amended soils [97], given that atrazine is a highly mobile and possibly carcinogenic compound with high groundwater pollution capacity [98,99].

Slow pyrolysis biochars may also be used as solid fuel. Biochars may have similar $\mathrm{H} / \mathrm{C}$ and $\mathrm{O} / \mathrm{C}$ ratios to coal, depending on the temperature and residence times, and high- 
quality solid fuels can be produced $[75,100,101]$. Biochars are also considered as promising solid fuels because of their low ash content compared to coal [21]. Co-combustion of low-grade coals with biochars was reported to improve their fuel properties [102]. The production of biochar-based solid fuels allows for a volume reduction of biomass in which large and fibrous biomass chunks are reduced to short and round particles with increased grindability properties thereby reducing the transport cost [100]. It has been argued that it is not economically efficient to transport low-density biomass beyond $96 \mathrm{~km}$ [103]. However, grindability also depends on feedstock type. For instance, Eucalyptus leaves show poor grindability properties even after $800{ }^{\circ} \mathrm{C}$ slow pyrolysis conditions [104]. The ash content of biomass may create slagging and fouling problems in combustion, e.g., some trouble elements in lignocellulosic biomass are chlorine and potassium [24,62,105]. Biochars with low $\mathrm{Si} / \mathrm{K}$ and $\mathrm{Ca} / \mathrm{K}$ ratios are likely to create slagging problems in fuel applications [104].

Another interesting use of the biochar is for adsorption of soil, water, and gas contaminants [106-108]. Adsorption of a number of inorganic and organic compounds was already tested with biochar [109-122]. Heavy metal adsorption is of particular interest, because adsorption is a very promising and low-cost process to remove metal ions in aqueous environments with a low-concentration range [7,123-125]. It is possible to enhance the adsorption properties of biochars by preparing activated carbons via chemical or physical activation $[126,127]$. However, the activation of biochar may not be necessary for adsorption of heavy metals [123]. In recent years, studies on adsorption of organic compounds by biochar have gained momentum because of the high affinity of organic compounds to biochar $[128,129]$. The tested organic compounds include polyaromatic hydrocarbons, polychlorinated biphenyls, pesticides, and herbicides [130-137]. The adsorption of organic molecules occurs differently from that of heavy metals [106]. Electrostatic and $\pi-\pi$ interactions are thought to be the main mechanisms in the organics' adsorption, while ionic interactions are regarded as the main mechanisms in the heavy metals' adsorption on biochar $[106,130]$. High-temperature biochars with increased surface area and aromaticity are likely to perform better in the adsorption of organic compounds [128]. Biochars may also be used for oil spill removals $[138,139]$. The oil removal capacities of biochars are lower than those of high-tech sorbents, but their low cost make them alternatives for oil spill removal [139]. The treatment of eutrophic waters, in particular the removal of phosphorus, is another interesting application of biochars. Although biochars showed poor selectivity and efficiency towards phosphorus in water, modification of biochars with several cations showed promising results [140-142]. Phosphorus-loaded biochars may, subsequently, be used in soil amendment [140,142].

In the recent years, biochar has been used in emerging applications such as catalysts for syngas cleaning, heterogeneous catalysts for hydrotreating bio-oil and Fischer-Tropsch synthesis, solid acid catalyst for biodiesel production, persulfate activator, supercapacitor electrode materials as well as cathode materials for Li-S batteries [109,110,143-148]. A further set of important applications of biochars are animal feed [149], production of direct carbon fuel cells (DCFCs), hydrogen storage or capacitive deionization (CDI) of wastewaters [150-152].

\subsection{Fast Pyrolysis}

The aim of fast pyrolysis is to obtain high amounts, up to $75 \%$, of condensable vapors (i.e., bio-oils) [45]. The pyrolysis conditions are set to ensure higher temperatures and heating rates $[15,18,45,153-155]$. Fast pyrolysis should not be confused with flash pyrolysis (ultra-fast pyrolysis) which is an extremely rapid thermal decomposition process to obtain gaseous products [156]. Approximately $15-20 \%$ char is obtained after fast pyrolysis [157]. The physical properties of fast pyrolysis chars are rather interesting, because they are different from those of the slow pyrolysis chars; in particular, they have lower surface areas and higher volatile content $[157,158]$. Fast pyrolysis chars can be used as fuel or as adsorbent with an optional activation [157-160], and since they are stable in soil, they may be used in amendment applications [161]. Recently, fast pyrolysis chars were proposed to 
be combined with fast pyrolysis liquids to produce bioslurries, a feedstock for gasification to produce drop-in fuels by the bioliq ${ }^{\mathrm{TM}}$ process $[160,162,163]$. Another interesting process design of fast pyrolysis is to produce biocoals by which biomass is first subjected to fast pyrolysis to obtain bio-oils followed by a distillation of fast pyrolysis oils to produce chemicals and a condensed bottom product called biocoal [164].

\subsection{Intermediate Pyrolysis}

Intermediate pyrolysis is carried out at lower heating rates and higher vapor residence times than fast pyrolysis, and approximately $30-40 \%$ char is obtained $[47,48]$. Intermediate pyrolysis chars were suggested for fuel or soil amendment applications based on the atomic $\mathrm{C}: \mathrm{O}$ ratio, moisture content, and heating values $[23,165,166]$. Intermediate pyrolysis at a large scale is a relatively new method for the production of biochars, and information on their properties is scarce compared to studies on fast and slow pyrolysis [48]. However, intermediate pyrolysis is an interesting process, because it is usually performed in screw (auger) reactors under controlled process conditions therefore allowing a wide range of process optimizations, ranging from heat carriers to gas flow rate, temperature, and solid residence times $[167,168]$. Screw reactors also have certain advantages over the conventional fast pyrolysis fluidized bed reactors such as inert gas requirements and feed size requirements [169]. The production of intermediate pyrolysis chars in screw reactors is an interesting process, because it is possible to obtain different target products at different positions of the reactor, i.e., cellulose-derived products at the middle and lignin-derived products at the tail [48]. Recently a new process called biothermal valorization of biomass (BtVB) was proposed to produce heat, energy, and charcoals based on the combination of intermediate pyrolysis and gasification $[170,171]$.

\subsection{Gasification}

Gasification is performed at the highest temperatures among the thermochemical methods. The aim of gasification is to produce gas products to be used for heat and power applications or synthetic fuels production [172]. However, in addition to gaseous products, gasification also produces approximately 5-10\% char. Gasification chars are physically and chemically different than slow pyrolysis and fast pyrolysis chars in particular regarding their high ash content, polyaromatic hydrocarbons, and higher aromaticity [17,157]. Soil amendment application may be suggested for high-ash gasification chars $[157,173,174]$, although their phytotoxicity may prevent their utilization in soil amendment $[17,175]$. Adsorption is also an alternative valorization route of gasification chars for substitution of activated carbons, since they were reported to have similar carbon content and pore structure as activated carbon [79]. As such, gasification chars may find applications in such as heavy metals adsorption or oil-spill remediation [176,177].

\subsection{Hydrothermal Carbonization}

Hydrothermal carbonization is carried out at the lowest temperature range among the thermochemical methods [17]. After hydrothermal carbonization approximately 55-90\% hydrochar is obtained with reduced ash content and increased heating value [17,178]. Hydrochars may be used as soil fuels in direct combustion or co-combustion with low-rank coals or they may be used as biochars in soil amendment applications [179-181]. They degrade more easily in soil than biochars and have acidic $\mathrm{pH}$ in contrast to the basic $\mathrm{pH}$ of slow pyrolysis chars [180-182] and they were also reported to retain the macro nutrients $\mathrm{N}, \mathrm{K}, \mathrm{Ca}, \mathrm{Mg}$, and P [183-185] thereby favoring their application in soil amendment. Hydrochars may also be used as adsorbents, although they have lower specific surface areas than biochars [184]. However, it is possible to enhance the adsorption properties of hydrochars by chemical or physical activation [186]. Hydrothermal carbonization can be combined with extraction and anaerobic digestion in a biorefinery scheme to produce platform chemicals and biogas in addition to hydrochar [187,188]. 
An overview of the applications of the charcoals is given in Figure 1, taking into account the above presented charcoal production methods from lignocellulosic biomass.

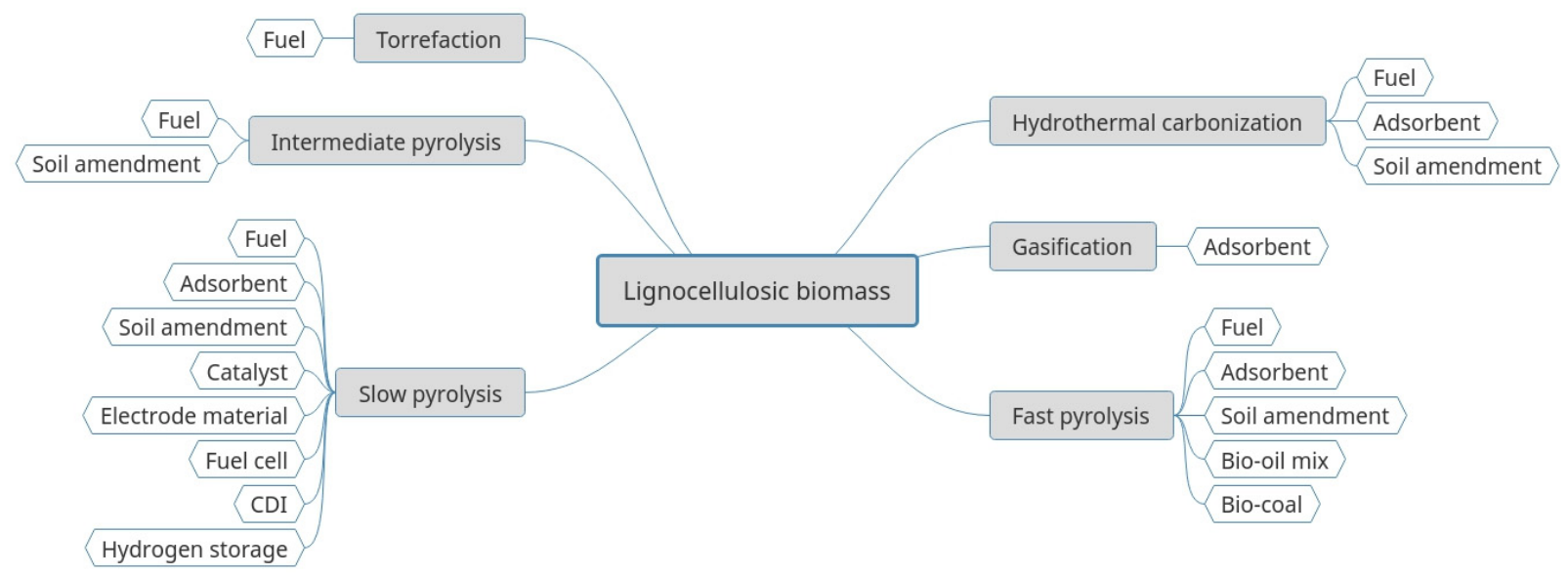

Figure 1. An overview of thermochemical treatments of biomass and of the applications of the resulting chars. Capacitive deionization, (CDI).

Therefore, different process conditions applied by thermochemical methods result in different types of chars. However, the process conditions alone are not sufficient for the maximization of char yields. The feedstock properties (physical and chemical properties such as moisture and ash contents, particle size, and chemical composition) should also be considered for a successful char production.

\section{Tree Barks and Other Lignocellulosic Materials: Chemical Differences}

A number of different pyrolysis methods have been applied to a wide range of lignocellulosic biomass including wood, bark, agricultural wastes, and energy crops [42,43]. Several studies have addressed the pyrolysis of wood for the production of bio-oils and biochars through fast and slow pyrolysis, respectively $[15,18,74]$. However, relatively little is known on the pyrolysis behavior of barks. This is not surprising, because bark is structurally more heterogeneous than wood, and its chemical composition is quite different from that of other lignocellulosic feedstocks [4,189-191]. It is well known that barks and agricultural wastes contain a higher amount of ash and a lower amount of carbohydrates than wood $[189,190,192,193]$. However, it is important to understand the specificity and diversity of the chemical composition of bark in detail before the application of a specific thermochemical method.

The characterization of the chemical composition of different barks is not a straightforward task because of the insufficient data available and the fact that only a minute proportion of barks have been studied out of the 60,065 tree species identified [194]. The relative importance of the different tree barks may be approximated by the number of research articles on the most frequently studied tree species in scientific data bases such as Web of Science in the last 15 years (Figures 2 and 3). This information may be helpful in the assessment of the relative importance of tree species and the potential of tree barks for industrial application or process development. A set of 34 softwood species and 47 hardwood species was identified as the most studied tree species (Figures 2 and 3). 


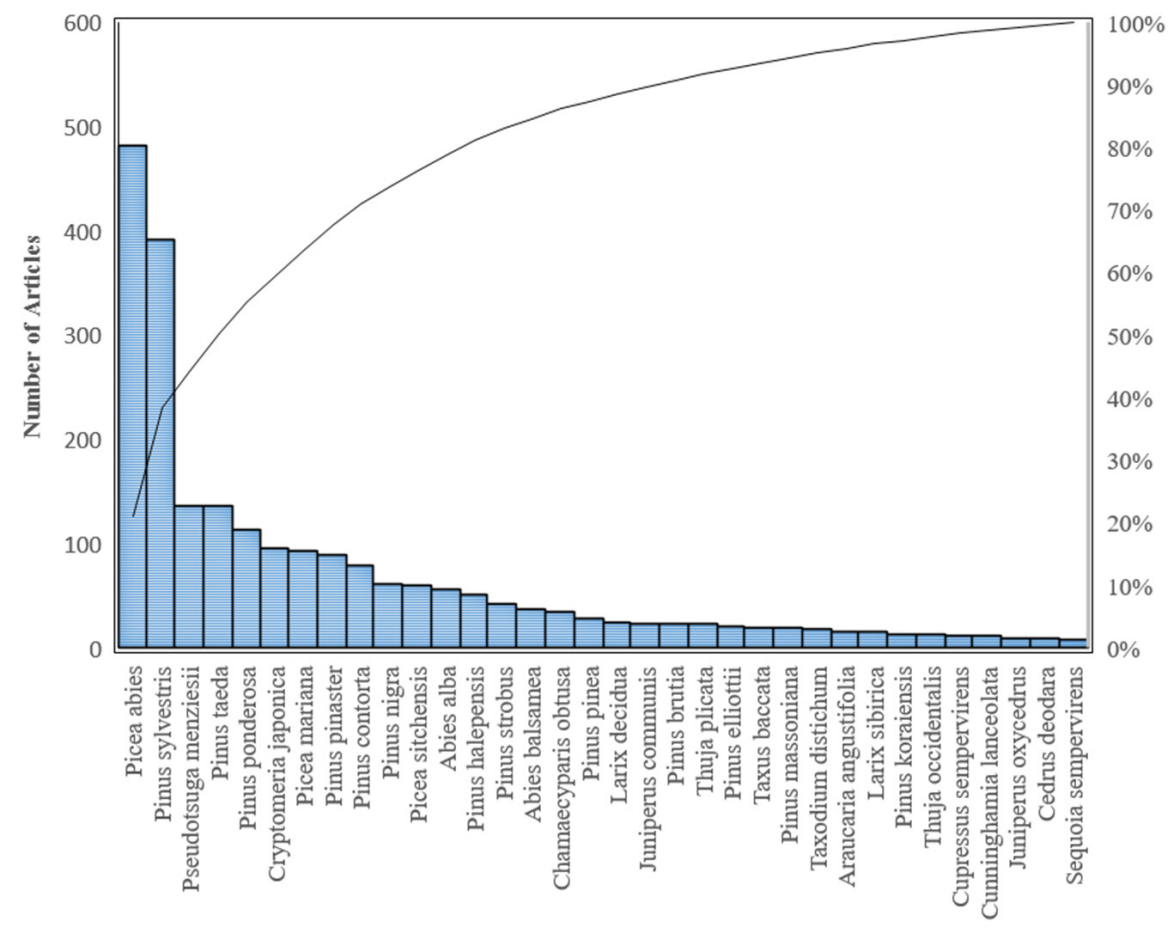

(a)

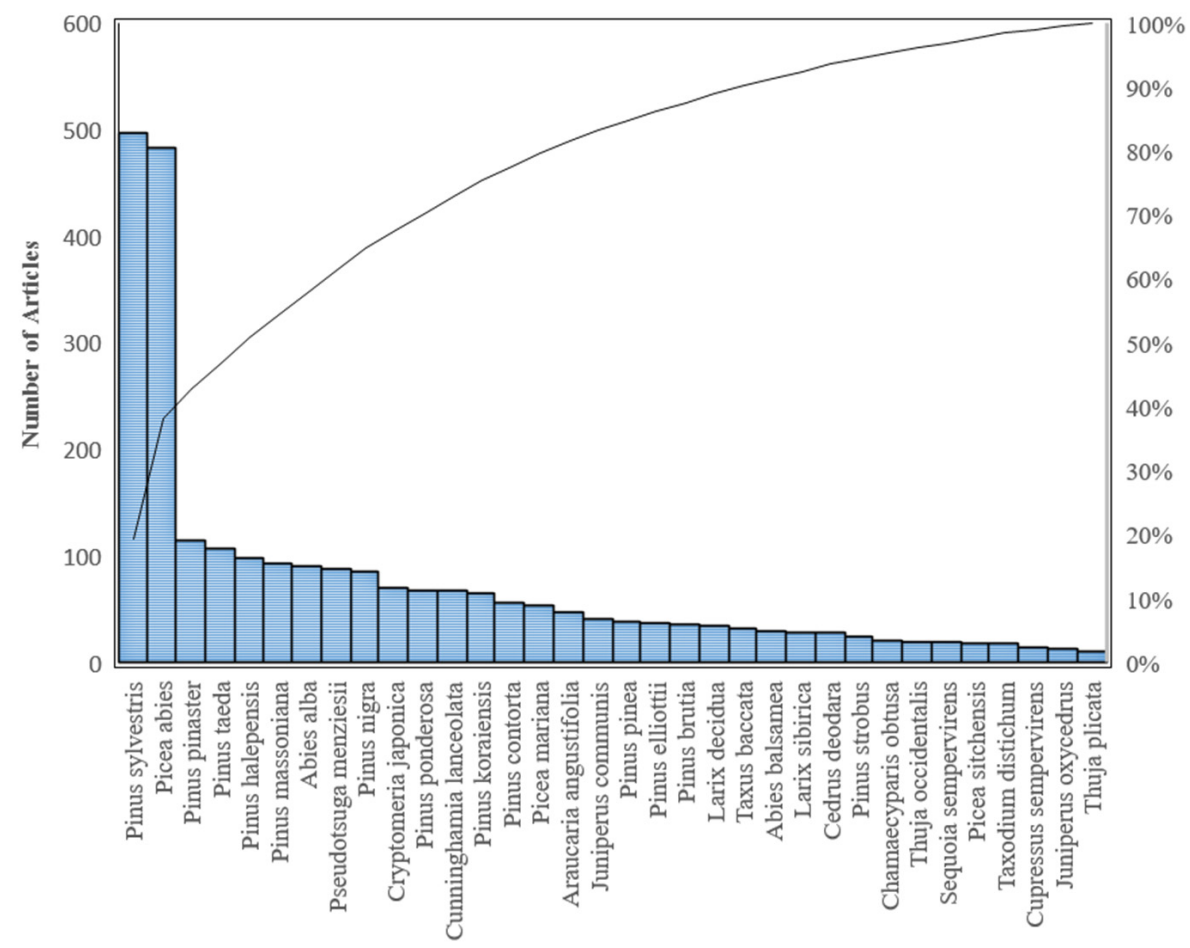

(b)

Figure 2. Most studied softwood tree species in 2006 (a) and in 2020 (b) shown as a Pareto chart, based on Web of Science data. 


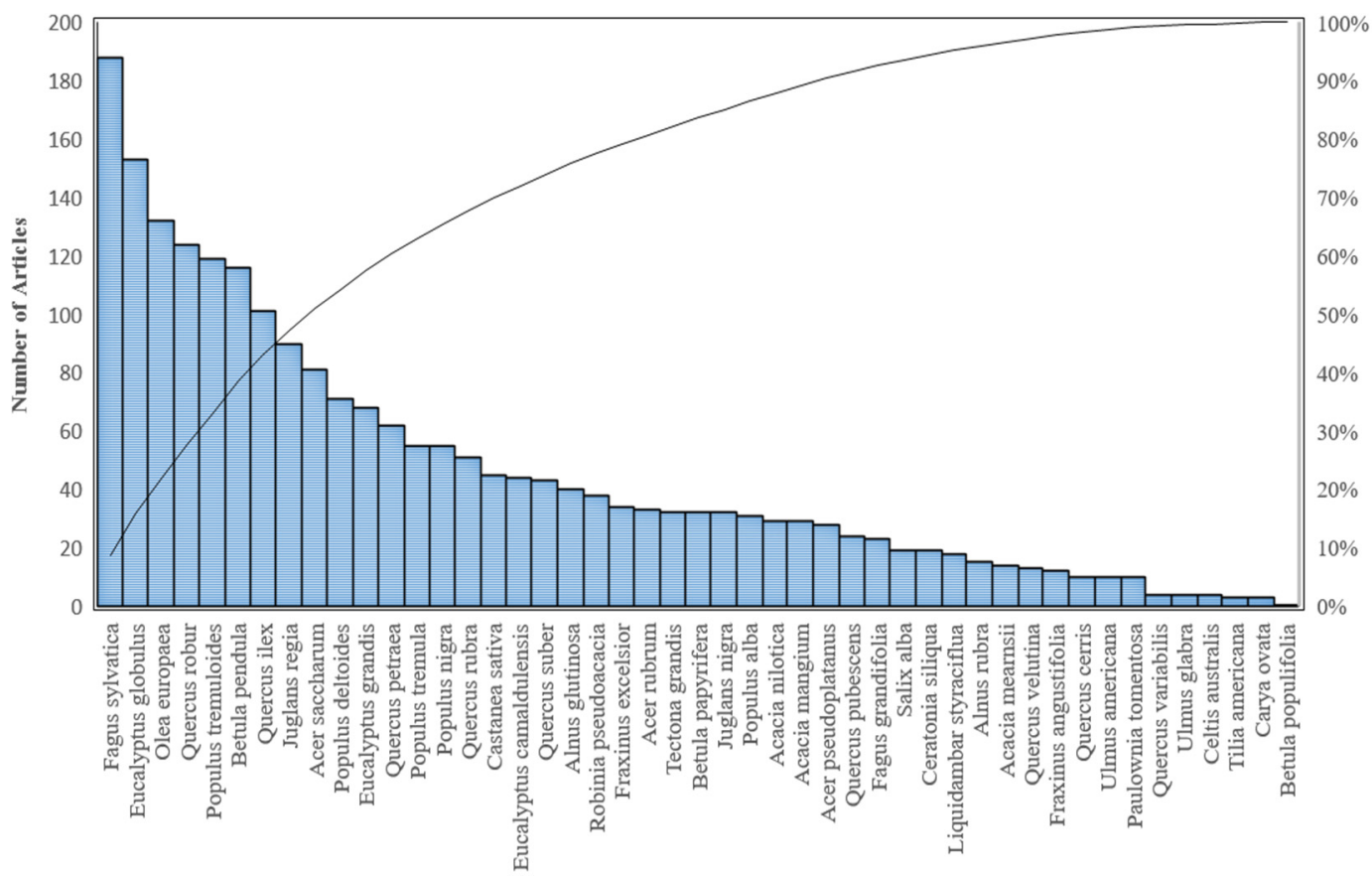

(a)

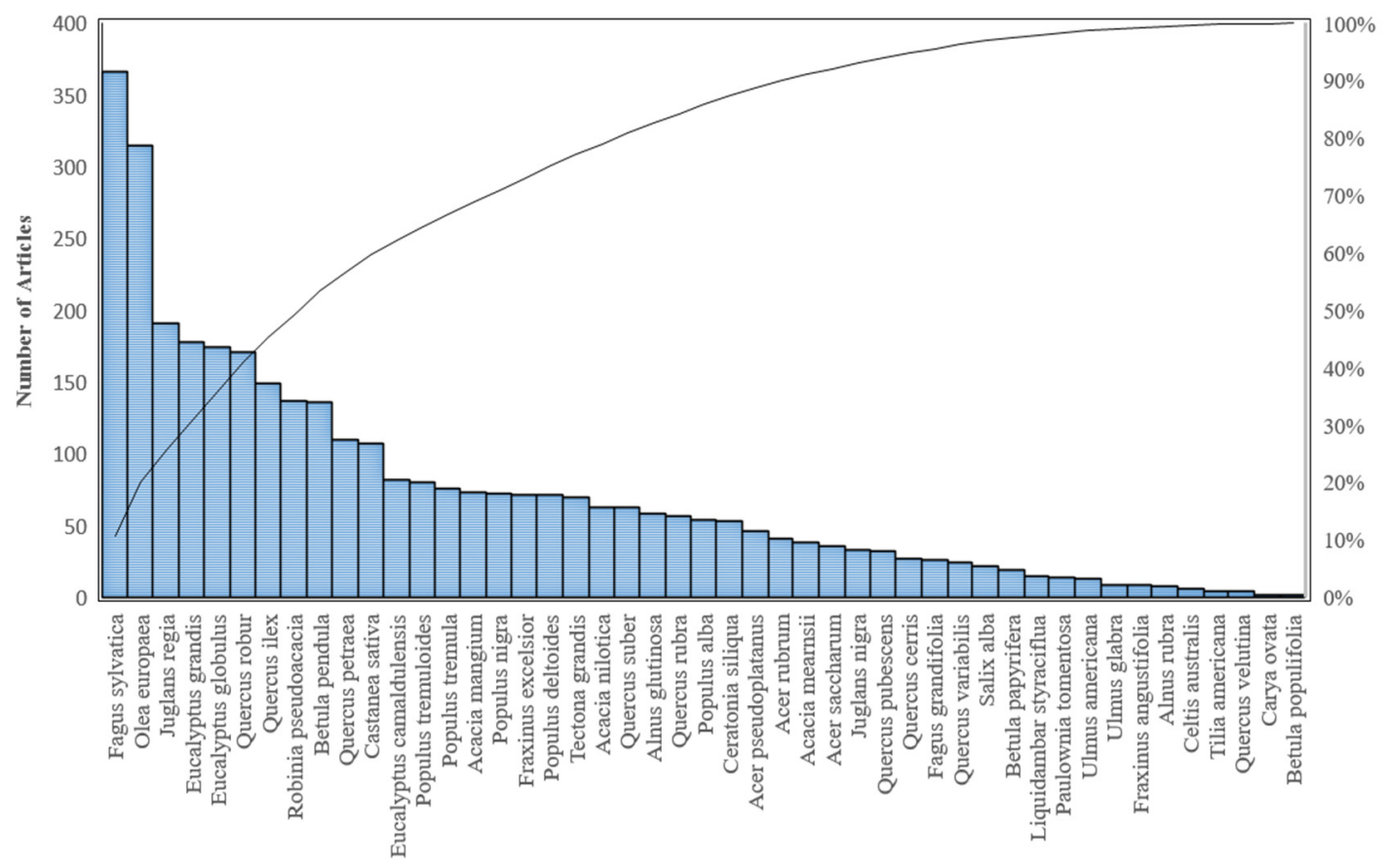

(b)

Figure 3. Most studied hardwood tree species in 2006 (above) and in 2020 (below) shown as a Pareto chart, based on Web of Science data.

The most studied hardwood families were Pinaceae in softwoods and Fagaceae and Salicaceae. Clearly, different aspects were analyzed in these research articles, and it is noteworthy that the number of publications is in line with the commercial relevance of the 
species, e.g., Pinus sylvestris and Fagus slyvatica for timber, Eucalyptus globulus for pulping or Olea europaea for olive oil.

Interestingly, while two softwood trees Scots pine (Pinus sylvestris) and Norway spruce (Picea abies) made up almost half of all softwoods studied, six hardwood species including European beech (Fagus sylvatica), olive tree (Olea europaea), pedunculate, evergreen oaks (Quercus robur and Quercus ilex, respectively), and eucalyptus trees (Eucalyptus grandis and Eucalyptus globulus) made up approximately half of the studies.

Many softwood and hardwood barks were not investigated, namely, when bark thickness was not sufficient to allow a commercial exploitation. Bark thickness is largely related to the formation of periderm and development of rhytidome (outer bark), and it is likely that tree barks with shaggy, deeply furrowed, scally or peeling rhytidome structures have potential for commercial exploitation depending on their chemical composition [195].

Despite being scarce, available data on the chemical composition of barks reveal some important features. The chemical composition of bark varies among different tree species and barks are considerably more heterogeneous than woods in the proportion of chemical components, differing between inner and outer bark sections and between hardwoods and softwoods [196,197]. In general, tree barks contain higher contents of inorganics (ash) and extractives and lower contents of cellulose than woods $[4,189]$. The presence of suberin is also a distinctive feature that differentiates bark from wood. For simplification, barks may be classified as softwood barks, hardwood barks, and cork-rich barks, and their chemical composition is compared with other lignocellulosic materials such as wood, agricultural wastes, and energy crops (Table 2).

Table 2. Differences in average chemical composition (\% dry mass) between bark and other lignocellulosic materials.

\begin{tabular}{cccccccc}
\hline \multicolumn{2}{c}{ Biomass Type } & Ash & Extract. & Polysaccharides & Suberin & Lignin & Reference \\
\hline \multirow{4}{*}{ Bark } & Softwood bark & 2 & 23 & 39 & 2 & 40 & {$[4,198-201]$} \\
& Hardwood bark & 8 & 16 & 44 & 3 & 30 & {$[4,202-205]$} \\
\multirow{5}{*}{ Wood } & Cork-rich bark & 3 & 21 & 18 & 34 & 32 & {$[206]$} \\
& Softwoods & 1 & 3 & 54 & - & 30 & {$[4,200,207]$} \\
& Hardwoods & 1 & 5 & 66 & - & 27 & {$[4,200,207]$} \\
\multirow{2}{*}{ Agricultural } & Wheat straw & 8 & 5 & 60 & - & 19 & {$[208]$} \\
wastes & Corn stover & 4 & 7 & 70 & - & 16 & {$[209]$} \\
\multirow{2}{*}{ Energy } & Sugarcane bagasse & 3 & 2 & 75 & - & 23 & {$[210]$} \\
crops & Rice husk & 16 & 4 & 53 & - & 27 & {$[211]$} \\
\hline
\end{tabular}

Moisture content is an important parameter in the processing of lignocellulosic biomass, since it affects size reduction, drying, storage, transport, and processing of biomass [214]. Wood contains approximately $50 \%$ of moisture at harvest which is higher than that of agricultural wastes (20\%) [214]. Moisture content of different lignocellulosic biomass types, including wood, agricultural wastes, and energy crops, measured by proximate analysis revealed that approximately $7-15 \%$ moisture is present in lignocellulosic materials at equilibrium conditions [215]. However, this value may not be taken in absolute terms, since the moisture content of lignocellulosic materials depends on the relative humidity, temperature, and pressure of the surrounding atmospheric conditions [216]. Since bark is exposed to atmospheric conditions, its moisture content varies between different species and between different seasons [6].

Barks contain higher amounts of inorganic material than woods but, when compared to agricultural wastes and energy crops, they have similar or less inorganic contents (Table 2). The most common elements in the inorganic fraction are calcium, magnesium, and potassium [200], and they are present as salts such as oxalates, phosphates, silicates $[4,189]$. Hardwood barks are likely to contain higher numbers of inorganics than 
softwood and cork-rich barks. The $\mathrm{pH}$ of the bark is generally lower than that of wood because of its higher inorganic content [200].

The extractive content is a distinctive feature of barks. Barks contain, in general, the highest number of extractives among the lignocellulosic materials wood, agricultural wastes, and energy crops (Table 2). They were reported to make up as high as $20-40 \%$ of the bark weight [189]. Extractives are non-structural components that may be solubilized by appropriate solvents and usually present a considerable diversity in terms of chemical families. The extractives of bark can be broadly grouped as lipophilic and hydrophilic compounds regarding their polarity. The variation of extractive composition can be large between different bark species even within the same genus [4].

The presence of suberin as a structural component of the phellem (cork) cells is another important distinctive chemical feature of bark, particularly in cork-rich barks (Table 2). Suberin is a macromolecule with structural functions in the cell wall that is characterized by an inter-esterified polymer of glycerol to long-chain carboxylic acids, hydroxy acids, and diacids. Suberin is the main component of the cork cell wall, e.g., about $40 \%$ of the dry weight of commercial cork material (cork of Quercus suber) with a mass ranging between $23 \%$ and $54 \%$ [206]. Depending on the species and on the cork proportion in the bark, suberin may represent between $2 \%$ and $45 \%$ of the structural chemical components of barks $[217,218]$.

Lignin content of barks is slightly higher than that of wood and considerably higher than of agricultural wastes and energy crops (Table 2). Lignin makes up approximately $15-30 \%$ of the extracted bark weight [189]. The extraction method is also important in determining lignin yield and the presence of extractives, such as hydrolysable, condensed tannins, and sulfuric acid-insoluble suberin, may lead to higher lignin yields [200]. The chemical composition of bark lignin is highly variable among species and, since bark is structurally heterogeneous, inner and outer barks may have different lignin compositions. For instance, the cork lignins from cork oak, Turkey oak, and birch outer barks have lignin compositions similar to those of softwood lignins (HG-lignins) $[189,219,220]$. Barks and agricultural wastes have a different lignin composition (HGS-lignin) from that of softwoods and hardwoods [221].

Polysaccharide (cellulose and hemicelluloses) content of bark is also an important chemical feature. Barks contain lower amounts of polysaccharides than wood, agricultural wastes, and energy crops (Table 2) with lower cellulose content, while the hemicelluloses content is nearly equal. The major hemicelluloses in softwood and hardwood barks are galactoglucomannans and arabino-4-O-methyl-glucuronoxylans, respectively, with a similar structure to those found in the corresponding woods [200].

Ultimate analysis of bark indicates that $\mathrm{C}, \mathrm{H}$, and $\mathrm{O}$ contents of softwoods and softwood barks were similar ( $C$ contents greater than $50 \%$ and $O$ contents were approximately $40 \%$ ) while hardwood barks contained higher amounts of $C$ and lower amounts of $O$ than hardwoods (C contents lower than $50 \%$ and $O$ contents greater than $40 \%$ ) [222,223]. Interestingly, cork-rich barks contained the highest amount of $\mathrm{C}$ and lowest amount of $\mathrm{O}$ among woods and barks ( $\mathrm{C}$ contents as high as $61 \%$ and $\mathrm{O}$ contents as low as $30 \%$ ), possibly due to the fact of their lower amount of polysaccharide contents [224,225]. Softwoods generally contain a higher amount of $\mathrm{C}$ and lower amount of $\mathrm{O}$ than hardwoods, but no statistical correlation was reported between hardwoods and softwoods indicating the heterogeneity of the elemental analysis results [226]. However, the higher calorific values reported for softwoods suggests a general elemental $(\mathrm{C}, \mathrm{H}, \mathrm{O})$ composition trend [227].

The overall results show that barks are a distinct type of lignocellulosic materials that is quite heterogeneous and chemically different from other lignocellulosic materials.

\section{Process Design for Bark-Based Char Production}

Barks have been applied in different thermochemical processes to produce chars. The chemical composition of barks, in particular their high ash and lignin contents, suggest their use in torrefaction, hydrothermal carbonization, slow pyrolysis, and intermediate 
pyrolysis [228-231]. However, barks have also been tested in fast pyrolysis, gasification, and hydrothermal carbonization [232-234].

The energy yields were reported to be lower in the torrefaction of eucalyptus barks compared to wood, and mass yields for bark were either lower or in the same order of those for wood $[228,229]$. These results probably result from the higher ash content of bark. Slow pyrolysis of Pinus brutia bark between $300{ }^{\circ} \mathrm{C}$ and $500{ }^{\circ} \mathrm{C}$ showed that charcoal yields increased with decreasing heating rate and varied between $59 \%$ and $42 \%$ [230]. Intermediate pyrolysis of pine and oak barks showed that charcoal yields were highly variable compared to pine and oak woods, and resulted in yields between $10 \%$ and $23 \%$ for pine bark and $21 \%$ and $28 \%$ for oak bark [231]. This variability in charcoal yields possibly result from the physical and chemical properties of bark. Fast pyrolysis of eucalyptus barks between $300{ }^{\circ} \mathrm{C}$ and $580{ }^{\circ} \mathrm{C}$ resulted in charcoal yields of $63 \%$ and $30 \%$, respectively [232]. Another fast pyrolysis study of Eucalyptus bark at $500^{\circ} \mathrm{C}$ resulted in charcoal yields between $24 \%$ and $30 \%$ [235]; this in line with the previous study. Fast pyrolysis of loblolly pine in wood-bark blends with increased bark percentage resulted in higher char and lower organic yields [236]. Gasification of bark-containing Eucalyptus benthamii biomass also showed that presence of bark increased charcoal yields and decreased gas yields [233]. Most gasification processes are sensitive to the presence of alkaline metals ( $\mathrm{Na}$ and $\mathrm{K}$ ) in the feedstock, since they may cause deposition or corrosion [237]. Thus, gasification processes may not be applied to high ash containing barks. Hydrothermal carbonization of Eucalyptus bark between $220^{\circ} \mathrm{C}$ and $300{ }^{\circ} \mathrm{C}$ resulted in hydrochar yields between $40 \%$ and $46 \%$ [234] which are lower than those obtained in dry torrefaction.

These studies show that barks have been used in thermochemical processes. However, since barks have a different chemical composition from wood, agricultural wastes, and energy crops, it is necessary to reconsider process design for the production of bark-based biochars and hydrochars. This task requires the evaluation of the process conditions and char yields with different bark feedstocks.

\subsection{A Review of Process Conditions}

Process conditions, such as temperature, residence time, heating rate, and reactor type, determine the product yields in addition to feedstock properties, in particular, particle size. Therefore, in order to develop bark-based charcoal productions it is necessary to evaluate the previous charcoal studies using bark as feedstock. Comparison of the studies in the last 15 years, in which an increased interest has been shown towards char properties, may be helpful to develop further studies [20] (Table 3).

Reactor types, heating rates, final temperatures, and residence times were highly variable, and a wide range of particle sizes were used. These factors resulted in variable charcoal yields.

Some authors did not refer to the scientific name of the bark species, although char yields depend on the chemical composition of the specific bark which may have high variability. There were also a few studies that used bark-based chars for different applications, but since they did not report the process conditions, they were excluded from Table 3 .

The effect of individual process variables on char yield may be analyzed and the temperature dependence of char yields may be visualized using a radar chart (Figure 4) based on the reported ranges of Table 3. As can be seen, temperature has a strong effect on the char yields of barks. 
Table 3. Studies on the charcoal production in the last 15 years using bark as a feedstock.

\begin{tabular}{|c|c|c|c|c|c|c|c|c|}
\hline Bark & Method * & $\begin{array}{l}\text { Reactor } \\
\text { Type }\end{array}$ & $\left(\begin{array}{c}\mathrm{HR} \\
\left({ }^{\circ} \mathrm{C} \mathrm{min}^{-1}\right)\end{array}\right.$ & $\begin{array}{c}\text { Particle Size } \\
(\mathrm{mm})\end{array}$ & $\begin{array}{c}\text { Char/Hydrochar } \\
\text { Yield (\%) }\end{array}$ & $\begin{array}{c}\mathrm{T} \\
\left({ }^{\circ} \mathrm{C}\right)\end{array}$ & $\underset{(\min )}{\operatorname{Tr}}$ & Reference \\
\hline Eucalyptus globulus & Torr & Lab-scale reactor & 10 & $2-4$ & $60-65$ & $250-280$ & $15-30$ & [229] \\
\hline Eucalyptus nitens & Torr & Lab-scale reactor & 10 & $2-4$ & $60-65$ & $250-280$ & $15-30$ & [229] \\
\hline Eucalyptus grandis & Torr & Temperature-controlled oven & 5 & $15 \times 110 \times 50$ & $73-88$ & $220-280$ & 60 & [228] \\
\hline Eucalyptus saligna & Torr & Temperature-controlled oven & 5 & $15 \times 120 \times 50$ & $71-88$ & $220-280$ & 60 & [228] \\
\hline Pine & Torr & Single particle oven & & $20 \times 10 \times 5$ & 83-99 & $240-320$ & $1-55$ & [238] \\
\hline Picea abies & Torr & Bench-scale tubular & 15 & $50-70$ & $61-90$ & $225-300$ & $30-60$ & [239] \\
\hline Eucalyptus & HTC & Autoclave reactor & & $3-5$ & $40-46$ & $220-300$ & $120-600$ & [234] \\
\hline Maesopsis eminii & Slow & Bench-scale fixed bed & 10 & & 32 & 500 & 60 & [76] \\
\hline Eucalyptus polybractea; & Slow & Fixed-bed & 10 & $10 \times 10 \times 0.3$ & $38-60$ & $300-500$ & 30 & [104] \\
\hline Leucaena leucocephala & Slow & Muffle furnace & & $20-30$ & 53 & $308-592$ & 35-205 & [240] \\
\hline Calophyllum inophyllum & Slow & Fixed-bed & 30 & 1.44 & $32-28$ & $450-600$ & & [241] \\
\hline Carpinus betulus & Slow & Fixed-bed & 7 & $0.5-1$ & $33-40$ & $400-600$ & 30 & [242] \\
\hline Oak & Int & Auger & & & $21-28$ & 450 & 0.5 & [231] \\
\hline Pine & Int & Auger & & & $10-23$ & 450 & 0.5 & [231] \\
\hline Azadirachta indica & Fast & Fluidized bed & & 0.71 & $24-38$ & $350-550$ & & [243] \\
\hline Eucalyptus globulus & Fast & Free-fall reactor & & $0.212-0.500$ & $22-40$ & $400-550$ & & [244] \\
\hline Birch & Fast & Bubbling fluidized bed & & 1 & $4-16$ & $500-550$ & & [245] \\
\hline Pseudotsuga menziesii & Fast & Tubular fixed-bed & 162 & & $38-42$ & $450-500$ & & [246] \\
\hline Pinus taeda & Fast & Tubular fixed bed & 162 & & $38-43$ & $450-500$ & & [246] \\
\hline Mallee & Fast & Fluidized bed & & $0.180-0.600$ & $30-60$ & $300-575$ & & [232] \\
\hline
\end{tabular}

* Torr: torrefaction, Int: intermediate pyrolysis, Slow: slow pyrolysis, Fast: fast pyrolysis, HTC: hydrothermal carbonization.

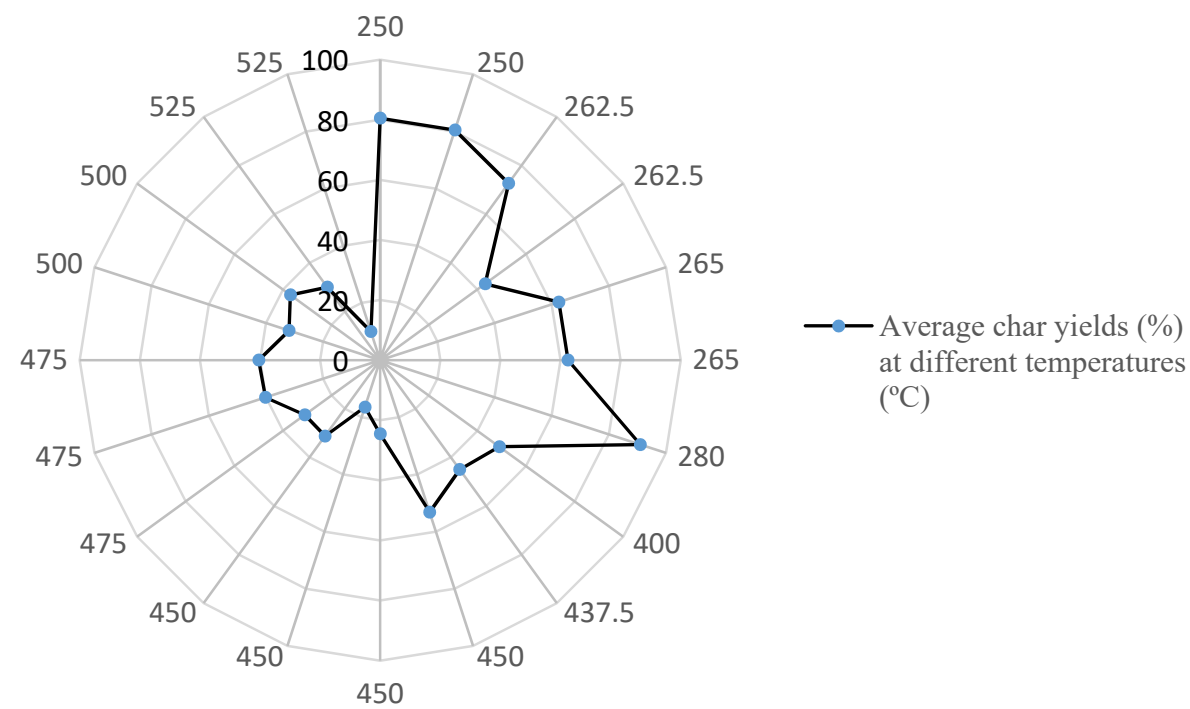

Figure 4. Temperature dependence of the char yields of the barks.

\subsection{Technology Selection}

After having analyzed the different char production process conditions and properties of the barks, a critical evaluation of bark as a feedstock material for thermochemical conversion was performed for guiding future char productions considering the described char production methods, the chemical composition of bark compared to other lignocellulosic materials, and the studies involving bark pyrolysis processes. Since the feedstock properties and process conditions are the important factors in the design and simulation of a thermochemical process [247], this evaluation may be useful for process design considerations. Therefore, the process design considerations in this review include feedstock-based (i.e., moisture content, ash content, grindability, and chemical composition) and processbased evaluations (i.e., torrefaction, slow pyrolysis, intermediate pyrolysis, fast pyrolysis, gasification, and hydrothermal carbonization) (Table 4). 
Table 4. Conditioning factors and potential of the thermochemical methods for bark-based charcoal production.

\begin{tabular}{|c|c|c|c|c|c|c|}
\hline \multirow[b]{2}{*}{ Processes } & \multicolumn{5}{|c|}{ Importance of the Conditioning Factors } & \multirow[b]{2}{*}{$\begin{array}{c}\text { Potential for Bark } \\
\text { Conversion }\end{array}$} \\
\hline & Moisture & Ash & $\begin{array}{l}\text { Particle } \\
\text { Size }\end{array}$ & Grindability & $\begin{array}{l}\text { Chemical } \\
\text { Composition }\end{array}$ & \\
\hline Torrefaction & Medium & Medium & Low & Medium & Low & High \\
\hline Slow pyrolysis & Low/Medium & Medium & Low & Low & Medium & High \\
\hline Intermediate pyrolysis & Medium & Medium & Low & High & Medium & Medium \\
\hline Fast pyrolysis & High & High & High & High & High & Low \\
\hline Gasification & High & High & High & High & High & Low \\
\hline $\begin{array}{l}\text { Hydrothermal } \\
\text { carbonization }\end{array}$ & - & Low & Low & Medium & Low & High \\
\hline
\end{tabular}

Moisture content is an important parameter in thermochemical processes, and fast pyrolysis and gasification processes are particularly sensitive to moisture content. As a rule of thumb, moisture contents should be lower than $10 \%$ in these applications $[15,19]$. Ash content is also important because barks contain high number of inorganics. The composition of ash is important, and alkaline metals, such as potassium and sodium, may be problematic in gasification and fast pyrolysis processes. On the other hand, these metals are beneficial for soil amendment applications. Hydrothermal carbonization is a promising method in the conversion of inorganic-rich barks to produce hydrochars considering the ash-related problems in dry pyrolysis methods. Low-temperature slow pyrolysis may also be another route for such barks for soil amendment applications considering the char yields.

Grindability of bark is usually improved after torrefaction. However, it is also necessary to grind bark prior to thermal treatments particularly in fast pyrolysis and gasification. The grindability properties of barks may be completely different from that of wood. The outer bark contains a cork fraction which has different mechanical properties from wood, e.g., cork has a high friction coefficient and compressibility and a Poisson ratio close to zero [248]. Therefore, grinding cork-rich barks may be challenging.

Barks are chemically different from other lignocellulosic materials, particularly in terms of their higher extractive and lower polysaccharide contents in addition to the presence of suberin. Their chemical composition suggests the use torrefaction, slow pyrolysis, and hydrothermal carbonization for the production of chars aimed for use in soil amendment or as fuel.

Torrefaction of bark should be performed at a higher temperature range for energy savings which can be controlled by using torrefaction severity indexes [69]. On the other hand, slow pyrolysis should be performed at temperatures that depend on the final applications of the char. For soil amendment, low temperatures and a high residence time combination are likely to give the best results by avoiding the formation of toxic phenolic compounds; while for adsorption and electrode materials applications, high temperatures are likely to be beneficial to ensure higher surface areas. Slow pyrolysis of cork-rich barks have a high potential for soil amendment, but this application is yet to be explored.

Biochars for soil amendment applications are usually produced from hardwoods, because they have a higher number of cells per volume than softwoods which is beneficial for soil biota. Recently, high temperature biochars of pine and eucalyptus woods were compared, and eucalyptus biochars showed higher micro-porosity, alkalinity, and electrostatic capacity [249]. When cork was analyzed, it could clearly be seen that it had a higher number of cells per unit volume than hardwoods, indicating a promising potential in char production [217] (Figure 5). 


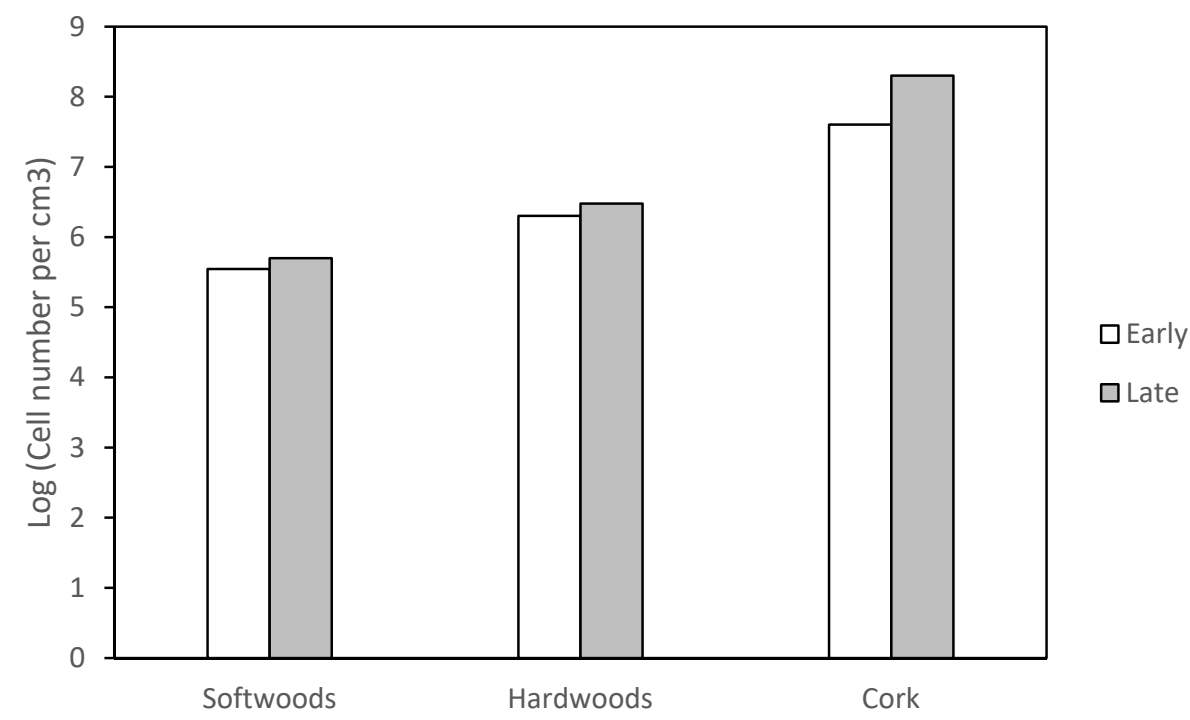

Figure 5. Comparison of the number of cells per $\mathrm{cm}^{3}$ in softwoods, hardwoods, and cork, corresponding to earlywood and latewood, and earlycork and latecork cells, respectively [217,250].

Intermediate pyrolysis, which is less sensitive to particle size than fast pyrolysis and gasification, may be applied to barks to produce biochars for soil amendment [166]. Fast pyrolysis and gasification processes are less likely to give good results with barks considering the possible operational problems due to the ash content and composition and low char yields. Hydrothermal carbonization should be tested with high-ash containing barks for soil amendment applications, because fuel and adsorption properties of chars are usually inferior to those of slow-pyrolysis biochars.

Among the different char production methods, slow pyrolysis is likely to be the best method to select when barks are used as feedstock, because slow pyrolysis chars have better surface properties (higher surface area and lower volatile content) than other chars in addition to their higher char yield. The surface properties of chars may be further enhanced by additional surface activation either by physical or chemical methods. Fast pyrolysis and gasification show lower char yields in addition to being sensitive to biomass properties summarized as conditioning factors. Therefore, they present a low potential for char production from barks.

Barks are often considered as residual materials and have lower cost than that of wood. The efficiency and economics of slow pyrolysis may be optimized by using the reaction products of non-condensable gases in the heating process and tars for different application such as plant protection [251].

\section{Conclusions}

Lignocellulosic charcoals are materials with interesting technological properties that may be used in different areas, particularly in fuel, soil amendment, and adsorption. Barks are among the important lignocellulosic biomass types that should be specifically studied, since they are heterogeneous materials and chemically different from other lignocellulosic materials. Studies on barks are scarce but the availability of barks as feedstocks may be approximated by analyzing most studied bark species. Thermochemical processes can be a promising approach to convert barks into valuable chars, but it is important to have information on the properties and chemical composition of the specific barks and to select proper process types and conditions to maximize char yields. The pyrolysis and gasification results of bark revealed that application of different particle sizes, heating rates, and solid residence times resulted in highly variable char yields between the temperature range of $220^{\circ} \mathrm{C}$ and $600{ }^{\circ} \mathrm{C}$. However, experimental data on bark characterization regarding thermochemical processing are still scarce, and targeted research on process optimization, product features, and application potential has to be carried out in order to have better 
valorization of this lignocellulosic biomass resource. Bark-based char production should be primarily performed via a slow pyrolysis route considering the superior surface properties of slow pyrolysis chars. Cork-rich barks show a promising potential for char production.

Author Contributions: Conceptualization, A.U.Ş.; Writing-Original draft preparation, A.U.Ş.: Supervision, H.P.; Writing-Reviewing and Editing, H.P. All authors have read and agreed to the published version of the manuscript.

Funding: This research was funded by [FCT-Fundação para a Ciência e a Tecnologia through funding to CEF] grant number [UIDB/00239/2020].

Institutional Review Board Statement: Not applicable.

Informed Consent Statement: Not applicable.

Data Availability Statement: Data sharing not applicable.

Acknowledgments: A.U.Ş. acknowledges support from FCT through a research contract (DL 57/2016).

Conflicts of Interest: The authors declare no conflict of interest.

\section{References}

1. FAO Unified Bioenergy Terminology. 2004. Available online: http:/ / www.fao.org/3/b-j4504e.pdf (accessed on 10 October 2020)

2. Union, E. Directive 2009/28/EC of the European Parliament and of the Council of 23 April 2009 on the promotion of the use of energy from renewable sources and amending and subsequently repealing Directives 2001/77/EC and 2003/30/EC. Off. J. Eur. Union 2009, 5, 2009.

3. Gerbens-Leenes, W.; Hoekstra, A.Y.; van der Meer, T.H. The water footprint of bioenergy. Proc. Natl. Acad. Sci. USA 2009, 106, 10219-10223. [CrossRef] [PubMed]

4. $\quad$ Fengel, D.; Wegener, G. Wood: Chemistry, Ultrastructure, Reactions; Walter de Gruyter: Berlin, Germany, 2011 ; ISBN 3110839652.

5. Harkin, J.M.; Rowe, J.W. Bark and Its Possible Uses; (Research note FPL; 091); Forest Products Laboratory: Madison, WI, USA, 1971; Volume 91, 56p.

6. Pasztory, Z.; Mohácsiné, I.R.; Gorbacheva, G.; Börcsök, Z. The utilization of tree bark. BioResources 2016, 11, 7859-7888. [CrossRef]

7. Şen, A.; Pereira, H.; Olivella, M.A.; Villaescusa, I. Heavy metals removal in aqueous environments using bark as a biosorbent. Int. J. Environ. Sci. Technol. 2015, 12, 391-404. [CrossRef]

8. Kemppainen, K.; Siika-aho, M.; Pattathil, S.; Giovando, S.; Kruus, K. Spruce bark as an industrial source of condensed tannins and non-cellulosic sugars. Ind. Crops Prod. 2014, 52, 158-168. [CrossRef]

9. Feng, S.; Cheng, S.; Yuan, Z.; Leitch, M.; Xu, C.C. Valorization of bark for chemicals and materials: A review. Renew. Sustain. Energy Rev. 2013, 26, 560-578. [CrossRef]

10. Holm-Nielsen, J.B.; Ehimen, E.A. Biorefinery plant design, engineering and process optimisation. In Advances in Biorefineries; Elsevier: Amsterdam, The Netherlands, 2014; pp. 89-111.

11. Cherubini, F. The biorefinery concept: Using biomass instead of oil for producing energy and chemicals. Energy Convers. Manag. 2010, 51, 1412-1421. [CrossRef]

12. Demirbas, A. Biorefineries: Current activities and future developments. Energy Convers. Manag. 2009, 50, 2782-2801. [CrossRef]

13. Waldron, K.W. Advances in Biorefineries: Biomass and Waste Supply Chain Exploitation; Elsevier: Amsterdam, The Netherlands, 2014; ISBN 0857097385.

14. Bridgwater, A.V. Renewable fuels and chemicals by thermal processing of biomass. Chem. Eng. J. 2003, 91, 87-102. [CrossRef]

15. Bridgwater, A.V.; Peacocke, G.V.C. Fast pyrolysis processes for biomass. Renew. Sustain. Energy Rev. 2000, 4, 1-73. [CrossRef]

16. Bridgwater, A.V. Fast pyrolysis of biomass for energy and fuels. In Thermochemical Conversion of Biomass to Liquid Fuels and Chemicals; Royal Society of Chemistry: London, UK, 2010; pp. 146-191.

17. Kambo, H.S.; Dutta, A. A comparative review of biochar and hydrochar in terms of production, physico-chemical properties and applications. Renew. Sustain. Energy Rev. 2015, 45, 359-378. [CrossRef]

18. Bridgwater, A.V.; Meier, D.; Radlein, D. An overview of fast pyrolysis of biomass. Org. Geochem. 1999, 30, 1479-1493. [CrossRef]

19. Bain, R.L.; Broer, K. Gasification; National Renewable Energy Lab. (NREL): Golden, CO, USA, 2011.

20. Chen, W.-H.; Peng, J.; Bi, X.T. A state-of-the-art review of biomass torrefaction, densification and applications. Renew. Sustain. Energy Rev. 2015, 44, 847-866. [CrossRef]

21. Nachenius, R.W.; Ronsse, F.; Venderbosch, R.H.; Prins, W. Biomass pyrolysis. In Advances in Chemical Engineering; Elsevier: Amsterdam, The Netherlands, 2013; Volume 42, pp. 75-139. ISBN 0065-2377.

22. Zhang, Z.; Zhu, Z.; Shen, B.; Liu, L. Insights into biochar and hydrochar production and applications: A review. Energy 2019, 171, 581-598. [CrossRef]

23. Mohammed, I.Y.; Abakr, Y.A.; Yusup, S.; Kazi, F.K. Valorization of Napier grass via intermediate pyrolysis: Optimization using response surface methodology and pyrolysis products characterization. J. Clean. Prod. 2017, 142, 1848-1866. [CrossRef] 
24. Shao, Y.; Wang, J.; Preto, F.; Zhu, J.; Xu, C. Ash deposition in biomass combustion or co-firing for power/heat generation. Energies 2012, 5, 5171-5189. [CrossRef]

25. Johnson, E. Goodbye to carbon neutral: Getting biomass footprints right. Environ. Impact Assess. Rev. 2009, 29, 165-168. [CrossRef]

26. Schlesinger, W.H. Are wood pellets a green fuel? Science 2018, 359, 1328-1329. [CrossRef]

27. Haberl, H.; Sprinz, D.; Bonazountas, M.; Cocco, P.; Desaubies, Y.; Henze, M.; Hertel, O.; Johnson, R.K.; Kastrup, U.; Laconte, P. Correcting a fundamental error in greenhouse gas accounting related to bioenergy. Energy Policy 2012, 45, 18-23. [CrossRef]

28. Nussbaumer, T. Combustion and co-combustion of biomass: Fundamentals, technologies, and primary measures for emission reduction. Energy Fuels 2003, 17, 1510-1521. [CrossRef]

29. Lehmann, J.; Joseph, S. Biochar for environmental management: An introduction. In Biochar for Environmental Management; Routledge: Abingdon, UK, 2015; pp. 33-46.

30. Ladygina, N.; Rineau, F. Biochar and Soil Biota; CRC Press: Boca Raton, FL, USA, 2013; ISBN 1466576480.

31. Ralebitso-Senior, T.K.; Orr, C.H. Biochar Application: Essential Soil Microbial Ecology; Elsevier: Amsterdam, The Netherlands, 2016; ISBN 012803436X.

32. Ok, Y.S.; Uchimiya, S.M.; Chang, S.X.; Bolan, N. Biochar: Production, Characterization, and Applications; CRC Press: Boca Raton, FL, USA, 2015; ISBN 1482242303.

33. Saletnik, B.; Zaguła, G.; Bajcar, M.; Tarapatskyy, M.; Bobula, G.; Puchalski, C. Biochar as a multifunctional component of the environment-A review. Appl. Sci. 2019, 9, 1139. [CrossRef]

34. Sarfraz, R.; Hussain, A.; Sabir, A.; Fekih, I.B.; Ditta, A.; Xing, S. Role of biochar and plant growth promoting rhizobacteria to enhance soil carbon sequestration-A review. Environ. Monit. Assess. 2019, 191, 251. [CrossRef] [PubMed]

35. Demirbas, A.; Ozturk, T.; Demirbas, M.F. Recovery of energy and chemicals from carbonaceous materials. Energy Sources Part A 2006, 28, 1473-1482. [CrossRef]

36. Brown, R. Biochar production technology. In Biochar for Environmental Management; Routledge: Abingdon, UK, 2012; pp. 127-143.

37. Tenenbaum, D.J. Biochar: Carbon mitigation from the ground up. Environ. Health Perspect. 2009, 117, A70-A73. [CrossRef] [PubMed]

38. Brownsort, P.A. Biomass Pyrolysis Processes: Performance Parameters and Their Influence on Biochar System Benefits. Master's Thesis, Science University of Edinburgh, Edinburgh, UK, 2009.

39. Tsai, W.-T. The potential of pyrolysing exhausted coffee residue for the production of biochar. In Handbook of Coffee Processing By-Products; Elsevier: Amsterdam, The Netherlands, 2017; pp. 299-322.

40. Bridgwater, A.V. Upgrading fast pyrolysis liquids. In Thermochemical Processing of Biomass: Conversion into Fuels, Chemicals and Power; John Wiley \& Sons, Inc.: Hoboken, NJ, USA, 2011; pp. 157-199.

41. Vamvuka, D. Bio-oil, solid and gaseous biofuels from biomass pyrolysis processes-An overview. Int. J. Energy Res. 2011, 35, 835-862. [CrossRef]

42. Dahlquist, E. Technologies for Converting Biomass to Useful Energy: Combustion, Gasification, Pyrolysis, Torrefaction and Fermentation; CRC Press: Boca Raton, FL, USA, 2013; ISBN 0415620880.

43. Brown, R.C. Thermochemical Processing of Biomass: Conversion into Fuels, Chemicals and Power; John Wiley \& Sons: Hoboken, NJ, USA, 2019; ISBN 1119417570.

44. Toor, S.S.; Rosendahl, L.; Rudolf, A. Hydrothermal liquefaction of biomass: A review of subcritical water technologies. Energy 2011, 36, 2328-2342. [CrossRef]

45. Bridgwater, A. V Review of fast pyrolysis of biomass and product upgrading. Biomass Bioenergy 2012, 38, 68-94. [CrossRef]

46. Demirbas, A.; Arin, G. An overview of biomass pyrolysis. Energy Sources 2002, 24, 471-482. [CrossRef]

47. Bridgwater, T. Challenges and opportunities in fast pyrolysis of biomass: Part I. Johns. Matthey Technol. Rev. 2018, 62, 118-130. [CrossRef]

48. Morgano, M.T.; Leibold, H.; Richter, F.; Seifert, H. Screw pyrolysis with integrated sequential hot gas filtration. J. Anal. Appl. Pyrolysis 2015, 113, 216-224. [CrossRef]

49. De Jongh, W.A.; Carrier, M.; Knoetze, J.H.H. Vacuum pyrolysis of intruder plant biomasses. J. Anal. Appl. Pyrolysis 2011, 92, 184-193. [CrossRef]

50. Wu, W.; Qiu, K. Vacuum co-pyrolysis of Chinese fir sawdust and waste printed circuit boards. Part II: Influence of heating conditions. J. Anal. Appl. Pyrolysis 2015, 111, 216-223. [CrossRef]

51. Garcia-Perez, M.; Chaala, A.; Pakdel, H.; Kretschmer, D.; Roy, C. Vacuum pyrolysis of softwood and hardwood biomass: Comparison between product yields and bio-oil properties. J. Anal. Appl. Pyrolysis 2007, 78, 104-116. [CrossRef]

52. Mermoud, F.; Salvador, S.; Van de Steene, L.; Golfier, F. Influence of the pyrolysis heating rate on the steam gasification rate of large wood char particles. Fuel 2006, 85, 1473-1482. [CrossRef]

53. Aljbour, S.H.; Kawamoto, K. Bench-scale gasification of cedar wood-Part I: Effect of operational conditions on product gas characteristics. Chemosphere 2013, 90, 1495-1500. [CrossRef]

54. Sermyagina, E.; Saari, J.; Kaikko, J.; Vakkilainen, E. Hydrothermal carbonization of coniferous biomass: Effect of process parameters on mass and energy yields. J. Anal. Appl. Pyrolysis 2015, 113, 551-556. [CrossRef]

55. Hoekman, S.K.; Broch, A.; Robbins, C.; Zielinska, B.; Felix, L. Hydrothermal carbonization (HTC) of selected woody and herbaceous biomass feedstocks. Biomass Convers. Biorefin. 2013, 3, 113-126. [CrossRef] 
56. Brand, S.; Hardi, F.; Kim, J.; Suh, D.J. Effect of heating rate on biomass liquefaction: Differences between subcritical water and supercritical ethanol. Energy 2014, 68, 420-427. [CrossRef]

57. Zhang, B.; von Keitz, M.; Valentas, K. Thermal effects on hydrothermal biomass liquefaction. In Biotechnology for Fuels and Chemicals; Springer: Berlin/Heidelberg, Germany, 2008; pp. 511-518.

58. Akhtar, J.; Amin, N.A.S. A review on process conditions for optimum bio-oil yield in hydrothermal liquefaction of biomass Renew. Sustain. Energy Rev. 2011, 15, 1615-1624. [CrossRef]

59. Yuan, X.Z.; Li, H.; Zeng, G.M.; Tong, J.Y.; Xie, W. Sub-and supercritical liquefaction of rice straw in the presence of ethanol-water and 2-propanol-water mixture. Energy 2007, 32, 2081-2088. [CrossRef]

60. Hwang, H.; Lee, J.H.; Choi, I.-G.; Choi, J.W. Comprehensive characterization of hydrothermal liquefaction products obtained from woody biomass under various alkali catalyst concentrations. Environ. Technol. 2019, 40, 1657-1667. [CrossRef] [PubMed]

61. Barskov, S.; Zappi, M.; Buchireddy, P.; Dufreche, S.; Guillory, J.; Gang, D.; Hernandez, R.; Bajpai, R.; Baudier, J.; Cooper, $\mathrm{R}$. Torrefaction of biomass: A review of production methods for biocoal from cultured and waste lignocellulosic feedstocks. Renew. Energy 2019, 142, 624-642. [CrossRef]

62. Niu, Y.; Lv, Y.; Lei, Y.; Liu, S.; Liang, Y.; Wang, D. Biomass torrefaction: Properties, applications, challenges, and economy. Renew. Sustain. Energy Rev. 2019, 115, 109395. [CrossRef]

63. Prins, M.J.; Ptasinski, K.J.; Janssen, F.J.J.G. Torrefaction of wood: Part 1. Weight loss kinetics. J. Anal. Appl. Pyrolysis 2006, 77, 28-34. [CrossRef]

64. Prins, M.J.; Ptasinski, K.J.; Janssen, F.J.J.G. Torrefaction of wood: Part 2. Analysis of products. J. Anal. Appl. Pyrolysis 2006, 77, 35-40. [CrossRef]

65. Ciolkosz, D.; Wallace, R. A review of torrefaction for bioenergy feedstock production. Biofuels Bioprod. Biorefin. 2011, 5, 317-329. [CrossRef]

66. Li, Y.-H.; Lin, H.-T.; Xiao, K.-L.; Lasek, J. Combustion behavior of coal pellets blended with Miscanthus biochar. Energy 2018, 163, 180-190. [CrossRef]

67. Chen, W.-H.; Huang, M.-Y.; Chang, J.-S.; Chen, C.-Y. Thermal decomposition dynamics and severity of microalgae residues in torrefaction. Bioresour. Technol. 2014, 169, 258-264. [CrossRef]

68. Chen, W.-H.; Cheng, C.-L.; Show, P.-L.; Ong, H.C. Torrefaction performance prediction approached by torrefaction severity factor. Fuel 2019, 251, 126-135. [CrossRef]

69. Zhang, C.; Ho, S.-H.; Chen, W.-H.; Xie, Y.; Liu, Z.; Chang, J.-S. Torrefaction performance and energy usage of biomass wastes and their correlations with torrefaction severity index. Appl. Energy 2018, 220, 598-604. [CrossRef]

70. Bach, Q.-V.; Tran, K.-Q.; Khalil, R.A.; Skreiberg, Ø.; Seisenbaeva, G. Comparative assessment of wet torrefaction. Energy Fuels 2013, 27, 6743-6753. [CrossRef]

71. Buss, W.; Mašek, O. Mobile organic compounds in biochar-A potential source of contamination-Phytotoxic effects on cress seed (Lepidium sativum) germination. J. Environ. Manag. 2014, 137, 111-119. [CrossRef] [PubMed]

72. Buss, W.; Mašek, O.; Graham, M.; Wüst, D. Inherent organic compounds in biochar-Their content, composition and potential toxic effects. J. Environ. Manag. 2015, 156, 150-157. [CrossRef] [PubMed]

73. Gascó, G.; Álvarez, M.L.; Paz-Ferreiro, J.; San Miguel, G.; Méndez, A. Valorization of biochars from pinewood gasification and municipal solid waste torrefaction as peat substitutes. Environ. Sci. Pollut. Res. 2018, 25, 26461-26469. [CrossRef]

74. Ronsse, F.; Van Hecke, S.; Dickinson, D.; Prins, W. Production and characterization of slow pyrolysis biochar: Influence of feedstock type and pyrolysis conditions. Gcb Bioenergy 2013, 5, 104-115. [CrossRef]

75. Liu, Z.; Han, G. Production of solid fuel biochar from waste biomass by low temperature pyrolysis. Fuel 2015, 158, 159-165. [CrossRef]

76. Lee, Y.; Park, J.; Ryu, C.; Gang, K.S.; Yang, W.; Park, Y.-K.; Jung, J.; Hyun, S. Comparison of biochar properties from biomass residues produced by slow pyrolysis at $500 \mathrm{C}$. Bioresour. Technol. 2013, 148, 196-201. [CrossRef]

77. Kloss, S.; Zehetner, F.; Dellantonio, A.; Hamid, R.; Ottner, F.; Liedtke, V.; Schwanninger, M.; Gerzabek, M.H.; Soja, G. Characterization of slow pyrolysis biochars: Effects of feedstocks and pyrolysis temperature on biochar properties. J. Environ. Qual. 2012, 41, 990-1000. [CrossRef]

78. Manyà, J.J. Pyrolysis for biochar purposes: A review to establish current knowledge gaps and research needs. Environ. Sci. Technol. 2012, 46, 7939-7954. [CrossRef]

79. Benedetti, V.; Patuzzi, F.; Baratieri, M. Characterization of char from biomass gasification and its similarities with activated carbon in adsorption applications. Appl. Energy 2018, 227, 92-99. [CrossRef]

80. Liang, B.; Lehmann, J.; Solomon, D.; Kinyangi, J.; Grossman, J.; O’neill, B.; Skjemstad, J.O.; Thies, J.; Luizão, F.J.; Petersen, J. Black carbon increases cation exchange capacity in soils. Soil Sci. Soc. Am. J. 2006, 70, 1719-1730. [CrossRef]

81. Laird, D.A.; Fleming, P.; Davis, D.D.; Horton, R.; Wang, B.; Karlen, D.L. Impact of biochar amendments on the quality of a typical Midwestern agricultural soil. Geoderma 2010, 158, 443-449. [CrossRef]

82. Major, J.; Steiner, C.; Downie, A. Biochar effects on nutrient leaching. In Biochar for Environmental Management; Lehmann, J., Joseph, S., Eds.; Routledge: Abingdon, UK, 2009; pp. 271-287.

83. Tanure, M.M.C.; da Costa, L.M.; Huiz, H.A.; Fernandes, R.B.A.; Cecon, P.R.; Junior, J.D.P.; da Luz, J.M.R. Soil water retention, physiological characteristics, and growth of maize plants in response to biochar application to soil. Soil Tillage Res. 2019, 192, 164-173. [CrossRef] 
84. Novak, J.M.; Busscher, W.J.; Laird, D.L.; Ahmedna, M.; Watts, D.W.; Niandou, M.A.S. Impact of biochar amendment on fertility of a southeastern coastal plain soil. Soil Sci. 2009, 174, 105-112. [CrossRef]

85. Glaser, B.; Wiedner, K.; Seelig, S.; Schmidt, H.-P.; Gerber, H. Biochar organic fertilizers from natural resources as substitute for mineral fertilizers. Agron. Sustain. Dev. 2015, 35, 667-678. [CrossRef]

86. Abel, S.; Peters, A.; Trinks, S.; Schonsky, H.; Facklam, M.; Wessolek, G. Impact of biochar and hydrochar addition on water retention and water repellency of sandy soil. Geoderma 2013, 202, 183-191. [CrossRef]

87. Cernansky, R. State-of-the-art soil. Nature 2015, 517, 258. [CrossRef]

88. Singh, B.; Singh, B.P.; Cowie, A.L. Characterisation and evaluation of biochars for their application as a soil amendment. Soil Res. 2010, 48, 516-525. [CrossRef]

89. Amonette, J.E.; Joseph, S. Characteristics of biochar: Microchemical properties. In Biochar for Environmental Management; Taylor \& Francis Group: Abingdon, UK, 2009; pp. 33-52.

90. Chan, K.Y.; Xu, Z. Biochar: Nutrient properties and their enhancement. Biochar Environ. Manag. Sci. Technol. 2009, 1, 67-84.

91. Yuan, J.-H.; Xu, R.-K.; Zhang, H. The forms of alkalis in the biochar produced from crop residues at different temperatures. Bioresour. Technol. 2011, 102, 3488-3497. [CrossRef]

92. Spokas, K.A.; Baker, J.M.; Reicosky, D.C. Ethylene: Potential key for biochar amendment impacts. Plant Soil 2010, 333, 443-452. [CrossRef]

93. Findenegg, G.R. A comparative study of ammonium toxicity at different constatn $\mathrm{pH}$ of the nutrient solution. Plant Soil 1987, 103, 239-243. [CrossRef]

94. Blackwell, P.; Riethmuller, G.; Collins, M. Biochar application to soil. Biochar Environ. Manag. Sci. Technol. 2009, 1, $207-226$.

95. Van Zwieten, L.; Kimber, S.; Morris, S.; Chan, K.Y.; Downie, A.; Rust, J.; Joseph, S.; Cowie, A. Effects of biochar from slow pyrolysis of papermill waste on agronomic performance and soil fertility. Plant Soil 2010, 327, 235-246. [CrossRef]

96. Lehmann, J.; Rillig, M.C.; Thies, J.; Masiello, C.A.; Hockaday, W.C.; Crowley, D. Biochar effects on soil biota-A review. Soil Biol. Biochem. 2011, 43, 1812-1836. [CrossRef]

97. Delwiche, K.B.; Lehmann, J.; Walter, M.T. Atrazine leaching from biochar-amended soils. Chemosphere 2014, 95, 346-352. [CrossRef]

98. Gupta, G.; Baummer, J., III. Biodegradation of atrazine in soil using poultry litter. J. Hazard. Mater. 1996, 45, 185-192. [CrossRef]

99. Belluck, D.A.; Benjamin, S.L.; Dawson, T. Groundwater Contamination by Atrazine and Its Metabolites: Risk Assessment, Policy, and Legal Implications; ACS Publications: Washington, DC, USA, 1991; ISBN 1947-5918.

100. Abdullah, H.; Wu, H. Biochar as a fuel: 1. Properties and grindability of biochars produced from the pyrolysis of mallee wood under slow-heating conditions. Energy Fuels 2009, 23, 4174-4181. [CrossRef]

101. Sadaka, S.; Sharara, M.A.; Ashworth, A.; Keyser, P.; Allen, F.; Wright, A. Characterization of biochar from switchgrass carbonization. Energies 2014, 7, 548-567. [CrossRef]

102. Haykiri-Acma, H.; Yaman, S. Synergistic investigation for co-combustion of biochars and lignite-Thermogravimetric analysis approach. J. Therm. Sci. Eng. Appl. 2019, 11, 011006. [CrossRef]

103. Garcia-Perez, M.; Lewis, T.; Kruger, C.E. Methods for Producing Biochar and Advanced Biofuels in Washington State; Washington State Department of Ecology: Spokane, WA, USA, 2010; Volume 137.

104. Abdullah, H.; Mediaswanti, K.A.; Wu, H. Biochar as a fuel: 2. Significant differences in fuel quality and ash properties of biochars from various biomass components of Mallee trees. Energy Fuels 2010, 24, 1972-1979. [CrossRef]

105. Misra, M.K.; Ragland, K.W.; Baker, A.J. Wood ash composition as a function of furnace temperature. Biomass Bioenergy 1993, 4, 103-116. [CrossRef]

106. Oliveira, F.R.; Patel, A.K.; Jaisi, D.P.; Adhikari, S.; Lu, H.; Khanal, S.K. Environmental application of biochar: Current status and perspectives. Bioresour. Technol. 2017, 246, 110-122. [CrossRef] [PubMed]

107. Ennis, C.J.; Evans, A.G.; Islam, M.; Ralebitso-Senior, T.K.; Senior, E. Biochar: Carbon sequestration, land remediation, and impacts on soil microbiology. Crit. Rev. Environ. Sci. Technol. 2012, 42, 2311-2364. [CrossRef]

108. Paz-Ferreiro, J.; Lu, H.; Fu, S.; Méndez, A.; Gascó, G. Use of phytoremediation and biochar to remediate heavy metal polluted soils: A review. Solid Earth 2014, 5, 65. [CrossRef]

109. Qian, K.; Kumar, A.; Zhang, H.; Bellmer, D.; Huhnke, R. Recent advances in utilization of biochar. Renew. Sustain. Energy Rev. 2015, 42, 1055-1064. [CrossRef]

110. Wang, J.; Wang, S. Preparation, modification and environmental application of biochar: A review. J. Clean. Prod. 2019, 227, 1002-1022. [CrossRef]

111. Reddy, D.H.K.; Lee, S.-M. Magnetic biochar composite: Facile synthesis, characterization, and application for heavy metal removal. Colloids Surfaces A Physicochem. Eng. Asp. 2014, 454, 96-103. [CrossRef]

112. Chintala, R.; Mollinedo, J.; Schumacher, T.E.; Papiernik, S.K.; Malo, D.D.; Clay, D.E.; Kumar, S.; Gulbrandson, D.W. Nitrate sorption and desorption in biochars from fast pyrolysis. Microporous Mesoporous Mater. 2013, 179, 250-257. [CrossRef]

113. Trakal, L.; Veselská, V.; Šafařík, I.; Vítková, M.; Číhalová, S.; Komárek, M. Lead and cadmium sorption mechanisms on magnetically modified biochars. Bioresour. Technol. 2016, 203, 318-324. [CrossRef]

114. Saiz-Rubio, R.; Balseiro-Romero, M.; Antelo, J.; Díez, E.; Fiol, S.; Macías, F. Biochar as low-cost sorbent of volatile fuel organic compounds: Potential application to water remediation. Environ. Sci. Pollut. Res. 2019, 26, 11605-11617. [CrossRef] [PubMed]

115. Gai, X.; Wang, H.; Liu, J.; Zhai, L.; Liu, S.; Ren, T.; Liu, H. Effects of feedstock and pyrolysis temperature on biochar adsorption of ammonium and nitrate. PLoS ONE 2014, 9, e113888. [CrossRef] [PubMed] 
116. Fan, S.; Wang, Y.; Wang, Z.; Tang, J.; Tang, J.; Li, X. Removal of methylene blue from aqueous solution by sewage sludge-derived biochar: Adsorption kinetics, equilibrium, thermodynamics and mechanism. J. Environ. Chem. Eng. 2017, 5, 601-611. [CrossRef]

117. Taghizadeh-Toosi, A.; Clough, T.J.; Sherlock, R.R.; Condron, L.M. Biochar adsorbed ammonia is bioavailable. Plant Soil 2012, 350, 57-69. [CrossRef]

118. Tong, X.; Li, J.; Yuan, J.; Xu, R. Adsorption of $\mathrm{Cu}$ (II) by biochars generated from three crop straws. Chem. Eng. J. 2011, 172, 828-834. [CrossRef]

119. Chen, X.; Chen, G.; Chen, L.; Chen, Y.; Lehmann, J.; McBride, M.B.; Hay, A.G. Adsorption of copper and zinc by biochars produced from pyrolysis of hardwood and corn straw in aqueous solution. Bioresour. Technol. 2011, 102, 8877-8884. [CrossRef]

120. Choudhary, B.; Paul, D. Isotherms, kinetics and thermodynamics of hexavalent chromium removal using biochar. J. Environ. Chem. Eng. 2018, 6, 2335-2343. [CrossRef]

121. Chen, Z.; Chen, B.; Zhou, D.; Chen, W. Bisolute sorption and thermodynamic behavior of organic pollutants to biomass-derived biochars at two pyrolytic temperatures. Environ. Sci. Technol. 2012, 46, 12476-12483. [CrossRef]

122. Jiang, T.-Y.; Jiang, J.; Xu, R.-K.; Li, Z. Adsorption of $\mathrm{Pb}$ (II) on variable charge soils amended with rice-straw derived biochar. Chemosphere 2012, 89, 249-256. [CrossRef]

123. Inyang, M.I.; Gao, B.; Yao, Y.; Xue, Y.; Zimmerman, A.; Mosa, A.; Pullammanappallil, P.; Ok, Y.S.; Cao, X. A review of biochar as a low-cost adsorbent for aqueous heavy metal removal. Crit. Rev. Environ. Sci. Technol. 2016, 46, 406-433. [CrossRef]

124. Boni, M.R.; Chiavola, A.; Marzeddu, S. Application of biochar to the remediation of Pb-contaminated solutions. Sustainability 2018, 10, 4440. [CrossRef]

125. Enaime, G.; Baçaoui, A.; Yaacoubi, A.; Lübken, M. Biochar for Wastewater Treatment-Conversion Technologies and Applications. Appl. Sci. 2020, 10, 3492. [CrossRef]

126. Azargohar, R.; Dalai, A.K. Biochar as a precursor of activated carbon. In Twenty-Seventh Symposium on Biotechnology for Fuels and Chemicals; Springer: Berlin/Heidelberg, Germany, 2006; pp. 762-773.

127. Azargohar, R.; Dalai, A.K. Steam and $\mathrm{KOH}$ activation of biochar: Experimental and modeling studies. Microporous Mesoporous Mater. 2008, 110, 413-421. [CrossRef]

128. Ahmad, M.; Lee, S.S.; Dou, X.; Mohan, D.; Sung, J.-K.; Yang, J.E.; Ok, Y.S. Effects of pyrolysis temperature on soybean stover-and peanut shell-derived biochar properties and TCE adsorption in water. Bioresour. Technol. 2012, 118, 536-544. [CrossRef]

129. Tan, X.; Liu, Y.; Zeng, G.; Wang, X.; Hu, X.; Gu, Y.; Yang, Z. Application of biochar for the removal of pollutants from aqueous solutions. Chemosphere 2015, 125, 70-85. [CrossRef]

130. Smernik, R.J. Biochar and sorption of organic compounds. Biochar Environ. Manag. Sci. Technol. 2009, $289-300$.

131. Dai, Y.; Zhang, N.; Xing, C.; Cui, Q.; Sun, Q. The adsorption, regeneration and engineering applications of biochar for removal organic pollutants: A review. Chemosphere 2019, 223, 12-27. [CrossRef]

132. Huang, Q.; Song, S.; Chen, Z.; Hu, B.; Chen, J.; Wang, X. Biochar-based materials and their applications in removal of organic contaminants from wastewater: State-of-the-art review. Biochar 2019, 1, 45-73. [CrossRef]

133. Chen, B.; Chen, Z. Sorption of naphthalene and 1-naphthol by biochars of orange peels with different pyrolytic temperatures. Chemosphere 2009, 76, 127-133. [CrossRef]

134. Taha, S.M.; Amer, M.E.; Elmarsafy, A.E.; Elkady, M.Y. Adsorption of 15 different pesticides on untreated and phosphoric acid treated biochar and charcoal from water. J. Environ. Chem. Eng. 2014, 2, 2013-2025. [CrossRef]

135. Martin, S.M.; Kookana, R.S.; Van Zwieten, L.; Krull, E. Marked changes in herbicide sorption-desorption upon ageing of biochars in soil. J. Hazard. Mater. 2012, 231, 70-78. [CrossRef] [PubMed]

136. Zheng, W.; Guo, M.; Chow, T.; Bennett, D.N.; Rajagopalan, N. Sorption properties of greenwaste biochar for two triazine pesticides. J. Hazard. Mater. 2010, 181, 121-126. [CrossRef] [PubMed]

137. Mandal, A.; Singh, N.; Purakayastha, T.J. Characterization of pesticide sorption behaviour of slow pyrolysis biochars as low cost adsorbent for atrazine and imidacloprid removal. Sci. Total Environ. 2017, 577, 376-385. [CrossRef] [PubMed]

138. Qin, G.; Gong, D.; Fan, M.-Y. Bioremediation of petroleum-contaminated soil by biostimulation amended with biochar. Int. Biodeterior. Biodegrad. 2013, 85, 150-155. [CrossRef]

139. Nguyen, H.N.; Pignatello, J.J. Laboratory tests of biochars as absorbents for use in recovery or containment of marine crude oil spills. Environ. Eng. Sci. 2013, 30, 374-380. [CrossRef]

140. Fang, C.; Zhang, T.; Li, P.; Jiang, R.; Wang, Y. Application of magnesium modified corn biochar for phosphorus removal and recovery from swine wastewater. Int. J. Environ. Res. Public Health 2014, 11, 9217-9237. [CrossRef]

141. Yin, Q.; Zhang, B.; Wang, R.; Zhao, Z. Biochar as an adsorbent for inorganic nitrogen and phosphorus removal from water: A review. Environ. Sci. Pollut. Res. 2017, 24, 26297-26309. [CrossRef]

142. Novais, S.V.; Zenero, M.D.O.; Barreto, M.S.C.; Montes, C.R.; Cerri, C.E.P. Phosphorus removal from eutrophic water using modified biochar. Sci. Total Environ. 2018, 633, 825-835. [CrossRef]

143. Ren, S.; Lei, H.; Wang, L.; Bu, Q.; Chen, S.; Wu, J. Hydrocarbon and hydrogen-rich syngas production by biomass catalytic pyrolysis and bio-oil upgrading over biochar catalysts. Rsc Adv. 2014, 4, 10731-10737. [CrossRef]

144. Kastner, J.R.; Miller, J.; Geller, D.P.; Locklin, J.; Keith, L.H.; Johnson, T. Catalytic esterification of fatty acids using solid acid catalysts generated from biochar and activated carbon. Catal. Today 2012, 190, 122-132. [CrossRef]

145. Wang, S.; Zhu, L.; Ma, Z. Biochar Production, Activation and Application as a Promising Catalyst. Sustain. Catal. Biorefin. 2018, 56,340 . 
146. Jin, H.; Wang, X.; Gu, Z.; Polin, J. Carbon materials from high ash biochar for supercapacitor and improvement of capacitance with HNO3 surface oxidation. J. Power Sources 2013, 236, 285-292. [CrossRef]

147. Qiu, Z.; Wang, Y.; Bi, X.; Zhou, T.; Zhou, J.; Zhao, J.; Miao, Z.; Yi, W.; Fu, P.; Zhuo, S. Biochar-based carbons with hierarchical micro-meso-macro porosity for high rate and long cycle life supercapacitors. J. Power Sources 2018, 376, 82-90. [CrossRef]

148. Gu, X.; Wang, Y.; Lai, C.; Qiu, J.; Li, S.; Hou, Y.; Martens, W.; Mahmood, N.; Zhang, S. Microporous bamboo biochar for lithium-sulfur batteries. Nano Res. 2015, 8, 129-139. [CrossRef]

149. Joseph, S.; Doug, P.O.W.; Dawson, K.; Mitchell, D.R.G.; Rawal, A.; Taherymoosavi, S.; van Zwieten, L.; Joshua, R.; Donne, S.; Munroe, P. Feeding biochar to cows: An innovative solution for improving soil fertility and farm productivity. Pedosphere 2015, 25, 666-679. [CrossRef]

150. Cha, J.S.; Park, S.H.; Jung, S.-C.; Ryu, C.; Jeon, J.-K.; Shin, M.-C.; Park, Y.-K. Production and utilization of biochar: A review. J. Ind. Eng. Chem. 2016, 40,1-15. [CrossRef]

151. Liu, W.-J.; Jiang, H.; Yu, H.-Q. Emerging applications of biochar-based materials for energy storage and conversion. Energy Environ. Sci. 2019, 12, 1751-1779. [CrossRef]

152. Dehkhoda, A.M.; Gyenge, E.; Ellis, N. A novel method to tailor the porous structure of KOH-activated biochar and its application in capacitive deionization and energy storage. Biomass Bioenergy 2016, 87, 107-121. [CrossRef]

153. Bridgwater, T. Fast pyrolysis based biorefineries. Chemistry (Easton) 2005, 4, 15-37.

154. Bridgwater, A. Fast pyrolysis of biomass for the production of liquids. In Biomass Combustion Science, Technology and Engineering; Elsevier: Amsterdam, The Netherlands, 2013; pp. 130-171.

155. Meier, D.; Faix, O. State of the art of applied fast pyrolysis of lignocellulosic materials-A review. Bioresour. Technol. 1999, 68, 71-77. [CrossRef]

156. Corella, J.; Monzon, A.; Santamaria, J.; González-Caníbano, J. Ultra-fast biomass pyrolysis in a high-temperature (2200 C), fluid-wall reactor. J. Sol. Energy Eng. 1988, 110, 11-13. [CrossRef]

157. Brewer, C.E.; Schmidt-Rohr, K.; Satrio, J.A.; Brown, R.C. Characterization of biochar from fast pyrolysis and gasification systems. Environ. Prog. Sustain. Energy An Off. Publ. Am. Inst. Chem. Eng. 2009, 28, 386-396. [CrossRef]

158. Funke, A.; Demus, T.; Willms, T.; Schenke, L.; Echterhof, T.; Niebel, A.; Pfeifer, H.; Dahmen, N. Application of fast pyrolysis char in an electric arc furnace. Fuel Process. Technol. 2018, 174, 61-68. [CrossRef]

159. Mohan, D.; Pittman, C.U., Jr.; Bricka, M.; Smith, F.; Yancey, B.; Mohammad, J.; Steele, P.H.; Alexandre-Franco, M.F.; GómezSerrano, V.; Gong, H. Sorption of arsenic, cadmium, and lead by chars produced from fast pyrolysis of wood and bark during bio-oil production. J. Colloid Interface Sci. 2007, 310, 57-73. [CrossRef] [PubMed]

160. Funke, A.; Niebel, A.; Richter, D.; Abbas, M.M.; Müller, A.-K.; Radloff, S.; Paneru, M.; Maier, J.; Dahmen, N.; Sauer, J. Fast pyrolysis char-Assessment of alternative uses within the bioliq ${ }^{\circledR}$ concept. Bioresour. Technol. 2016, 200, 905-913. [CrossRef] [PubMed]

161. Brewer, C.E.; Hu, Y.; Schmidt-Rohr, K.; Loynachan, T.E.; Laird, D.A.; Brown, R.C. Extent of pyrolysis impacts on fast pyrolysis biochar properties. J. Environ. Qual. 2012, 41, 1115-1122. [CrossRef] [PubMed]

162. Dahmen, N.; Henrich, E.; Dinjus, E.; Weirich, F. The bioliq ${ }^{\circledR}$ bioslurry gasification process for the production of biosynfuels, organic chemicals, and energy. Energy. Sustain. Soc. 2012, 2, 3. [CrossRef]

163. Dahmen, N.; Dinjus, E.; Kolb, T.; Arnold, U.; Leibold, H.; Stahl, R. State of the art of the bioliq ${ }^{\circledR}$ process for synthetic biofuels production. Environ. Prog. Sustain. Energy 2012, 31, 176-181. [CrossRef]

164. Cheng, B.-H.; Huang, B.-C.; Zhang, R.; Chen, Y.-L.; Jiang, S.-F.; Lu, Y.; Zhang, X.-S.; Jiang, H.; Yu, H.-Q. Bio-coal: A renewable and massively producible fuel from lignocellulosic biomass. Sci. Adv. 2020, 6, eaay0748. [CrossRef]

165. Neumann, J.; Binder, S.; Apfelbacher, A.; Gasson, J.R.; García, P.R.; Hornung, A. Production and characterization of a new quality pyrolysis oil, char and syngas from digestate-Introducing the thermo-catalytic reforming process. J. Anal. Appl. Pyrolysis 2015, 113, 137-142. [CrossRef]

166. Yang, Y.; Brammer, J.G.; Mahmood, A.S.N.; Hornung, A. Intermediate pyrolysis of biomass energy pellets for producing sustainable liquid, gaseous and solid fuels. Bioresour. Technol. 2014, 169, 794-799. [CrossRef] [PubMed]

167. Dhyani, V.; Bhaskar, T. A comprehensive review on the pyrolysis of lignocellulosic biomass. Renew. Energy 2018, 129, 695-716. [CrossRef]

168. Brassard, P.; Godbout, S.; Raghavan, V. Pyrolysis in auger reactors for biochar and bio-oil production: A review. Biosyst. Eng. 2017, 161, 80-92. [CrossRef]

169. Campuzano, F.; Brown, R.C.; Martínez, J.D. Auger reactors for pyrolysis of biomass and wastes. Renew. Sustain. Energy Rev. 2019, 102, 372-409. [CrossRef]

170. Hornung, A. Intermediate pyrolysis of biomass. In Biomass Combustion Science, Technology and Engineering; Elsevier: Amsterdam, The Netherlands, 2013; pp. 172-186.

171. Hornung, A.; Apfelbacher, A.; Sagi, S. Intermediate pyrolysis: A sustainable biomass-to-energy concept—Biothermal valorisation of biomass BtVB process. J. Sci. Ind. Res. 2011, 70, 664-667.

172. Kumar, A.; Jones, D.D.; Hanna, M.A. Thermochemical biomass gasification: A review of the current status of the technology. Energies 2009, 2, 556-581. [CrossRef]

173. Carter, S.; Shackley, S.; Sohi, S.; Suy, T.B.; Haefele, S. The impact of biochar application on soil properties and plant growth of pot grown lettuce (Lactuca sativa) and cabbage (Brassica chinensis). Agronomy 2013, 3, 404-418. [CrossRef] 
174. Deal, C.; Brewer, C.E.; Brown, R.C.; Okure, M.A.E.; Amoding, A. Comparison of kiln-derived and gasifier-derived biochars as soil amendments in the humid tropics. Biomass Bioenergy 2012, 37, 161-168. [CrossRef]

175. Patuzzi, F.; Prando, D.; Vakalis, S.; Rizzo, A.M.; Chiaramonti, D.; Tirler, W.; Mimmo, T.; Gasparella, A.; Baratieri, M. Small-scale biomass gasification CHP systems: Comparative performance assessment and monitoring experiences in South Tyrol (Italy). Energy 2016, 112, 285-293. [CrossRef]

176. Godinho, D.; Dias, D.; Bernardo, M.; Lapa, N.; Fonseca, I.; Lopes, H.; Pinto, F. Adding value to gasification and co-pyrolysis chars as removal agents of $\mathrm{Cr}^{3+}$. J. Hazard. Mater. 2017, 321, 173-182. [CrossRef]

177. Silvani, L.; Vrchotova, B.; Kastanek, P.; Demnerova, K.; Pettiti, I.; Papini, M.P. Characterizing biochar as alternative sorbent for oil spill remediation. Sci. Rep. 2017, 7, 43912. [CrossRef] [PubMed]

178. Yan, W.; Hastings, J.T.; Acharjee, T.C.; Coronella, C.J.; Vásquez, V.R. Mass and energy balances of wet torrefaction of lignocellulosic biomass. Energy Fuels 2010, 24, 4738-4742. [CrossRef]

179. Liu, Z.; Quek, A.; Hoekman, S.K.; Balasubramanian, R. Production of solid biochar fuel from waste biomass by hydrothermal carbonization. Fuel 2013, 103, 943-949. [CrossRef]

180. Bargmann, I.; Martens, R.; Rillig, M.C.; Kruse, A.; Kücke, M. Hydrochar amendment promotes microbial immobilization of mineral nitrogen. J. Plant Nutr. Soil Sci. 2014, 177, 59-67. [CrossRef]

181. Libra, J.A.; Ro, K.S.; Kammann, C.; Funke, A.; Berge, N.D.; Neubauer, Y.; Titirici, M.-M.; Fühner, C.; Bens, O.; Kern, J. Hydrothermal carbonization of biomass residuals: A comparative review of the chemistry, processes and applications of wet and dry pyrolysis. Biofuels 2011, 2, 71-106. [CrossRef]

182. Weber, K.; Quicker, P. Properties of biochar. Fuel 2018, 217, 240-261. [CrossRef]

183. Funke, A.; Mumme, J.; Koon, M.; Diakité, M. Cascaded production of biogas and hydrochar from wheat straw: Energetic potential and recovery of carbon and plant nutrients. Biomass Bioenergy 2013, 58, 229-237. [CrossRef]

184. Dieguez-Alonso, A.; Funke, A.; Anca-Couce, A.; Rombolà, A.G.; Ojeda, G.; Bachmann, J.; Behrendt, F. Towards biochar and hydrochar engineering-Influence of process conditions on surface physical and chemical properties, thermal stability, nutrient availability, toxicity and wettability. Energies 2018, 11, 496. [CrossRef]

185. Melo, C.A.; Junior, F.H.S.; Bisinoti, M.C.; Moreira, A.B.; Ferreira, O.P. Transforming sugarcane bagasse and vinasse wastes into hydrochar in the presence of phosphoric acid: An evaluation of nutrient contents and structural properties. Waste Biomass Valorization 2017, 8, 1139-1151. [CrossRef]

186. Sevilla, M.; Ferrero, G.A.; Fuertes, A.B. Beyond KOH activation for the synthesis of superactivated carbons from hydrochar. Carbon N. Y. 2017, 114, 50-58. [CrossRef]

187. Stökle, K.; Hülsemann, B.; Steinbach, D.; Cao, Z.; Oechsner, H.; Kruse, A. A biorefinery concept using forced chicory roots for the production of biogas, hydrochar, and platform chemicals. Biomass Convers. Biorefinery 2019, 1-11. [CrossRef]

188. Poerschmann, J.; Weiner, B.; Wedwitschka, H.; Baskyr, I.; Koehler, R.; Kopinke, F.-D. Characterization of biocoals and dissolved organic matter phases obtained upon hydrothermal carbonization of brewer's spent grain. Bioresour. Technol. 2014, 164, 162-169. [CrossRef] [PubMed]

189. Sjostrom, E. Wood Chemistry: Fundamentals and Applications; Gulf Professional Publishing: Houston, TX, USA, 1993; ISBN 0126474818.

190. Sakai, K. Chemistry of bark. In Wood and Cellulosic Chemistry; CRC Press: Boca Raton, FL, USA, 2000; pp. $243-274$.

191. Esau, K. Structure and Development of the Bark in Dicotyledons. In Proceedings of the The Formation of Wood in Forest Trees: The Second Symposium Held under the Auspices of the Maria Moors Cabot Foundation for Botanical Research, Harvard Forest, Petersham, MA, USA, 15-19 April 1963; Elsevier: Amsterdam, The Netherlands, 2013; p. 37.

192. Vamvuka, D.; Zografos, D. Predicting the behaviour of ash from agricultural wastes during combustion. Fuel 2004, 83, $2051-2057$. [CrossRef]

193. Aprianti, E.; Shafigh, P.; Bahri, S.; Farahani, J.N. Supplementary cementitious materials origin from agricultural wastes-A review. Constr. Build. Mater. 2015, 74, 176-187. [CrossRef]

194. Beech, E.; Rivers, M.; Oldfield, S.; Smith, P.P. GlobalTreeSearch: The first complete global database of tree species and country distributions. J. Sustain. For. 2017, 36, 454-489. [CrossRef]

195. Evert, R.F. Esau's Plant Anatomy: Meristems, Cells, and Tissues of the Plant Body: Their StrucTure, Function, and Development; John Wiley \& Sons: Hoboken, NJ, USA, 2006; ISBN 0470047372.

196. Pereira, H. The importance of biomass structure and chemical composition for biorefineries. In Proceedings of the 2012 IUFRO Conference Division 5 Forest Products, Estoril, Lisbon, Portugal, 8-13 July 2012; Final program, Proceedings and Abstracts Book. IUFRO (International Union of Forestry Research Organizations): Vienna, Austria, 2012; pp. 57-62.

197. Tsoumis, G. Wood as Raw Material: Source, Structure, Chemical Composition, Growth, Degradation and Identification; Elsevier: Amsterdam, The Netherlands, 2013; ISBN 1483159523.

198. Kofujita, H.; Ettyu, K.; Ota, M. Characterization of the major components in bark from five Japanese tree species for chemical utilization. Wood Sci. Technol. 1999, 33, 223-228. [CrossRef]

199. Miranda, I.; Gominho, J.; Mirra, I.; Pereira, H. Chemical characterization of barks from Picea abies and Pinus sylvestris after fractioning into different particle sizes. Ind. Crops Prod. 2012, 36, 395-400. [CrossRef]

200. Rowell, R.M. Handbook of Wood Chemistry and Wood Composites; CRC Press: Boca Raton, FL, USA, 2012 ; ISBN 0429109091.

201. Nunes, E.; Quilhó, T.; Pereira, H. Anatomy and chemical composition of Pinus pinaster bark. IAWA J. 1996, 17, 141-150. [CrossRef] 
202. Hemalatha, N.; Remadevi, O.K.; Singh, K.C.; Ramanigopal, C. Chemical characterization of Acacia nilotica tree parts. J. Indian Acad. Wood Sci. 2012, 9, 33-39. [CrossRef]

203. Harun, J.; Labosky, P. Chemical constituents of five northeastern barks. Wood Fiber Sci. 2007, 17, $274-280$.

204. Sillero, L.; Prado, R.; Andrés, M.A.; Labidi, J. Characterisation of bark of six species from mixed Atlantic forest. Ind. Crop. Prod. 2019, 137, 276-284. [CrossRef]

205. Miranda, I.; Gominho, J.; Mirra, I.; Pereira, H. Fractioning and chemical characterization of barks of Betula pendula and Eucalyptus globulus. Ind. Crop. Prod. 2013, 41, 299-305. [CrossRef]

206. Leite, C.; Pereira, H. Cork-containing barks-A review. Front. Mater. 2017, 3, 63. [CrossRef]

207. Balat, M.; Balat, M.; Kırtay, E.; Balat, H. Main routes for the thermo-conversion of biomass into fuels and chemicals. Part 1: Pyrolysis systems. Energy Convers. Manag. 2009, 50, 3147-3157. [CrossRef]

208. Jin, Y.; Huang, T.; Geng, W.; Yang, L. Comparison of sodium carbonate pretreatment for enzymatic hydrolysis of wheat straw stem and leaf to produce fermentable sugars. Bioresour. Technol. 2013, 137, 294-301. [CrossRef]

209. Cheng, H.; Zhan, H.; Fu, S.; Lucia, L.A. Alkali extraction of hemicellulose from depithed corn stover and effects on soda-AQ pulping. BioResources 2011, 6, 196-206.

210. da Silva, A.S.; Lee, S.-H.; Endo, T.; Bon, E.P.S. Major improvement in the rate and yield of enzymatic saccharification of sugarcane bagasse via pretreatment with the ionic liquid 1-ethyl-3-methylimidazolium acetate ([Emim][Ac]). Bioresour. Technol. 2011, 102, 10505-10509. [CrossRef]

211. e Paula, L.E.D.R.; Trugilho, P.F.; Napoli, A.; Bianchi, M.L. Characterization of residues from plant biomass for use in energy generation. Cerne 2015, 17, 237-246. [CrossRef]

212. Kline, L.M.; Labbé, N.; Boyer, C.; Yu, T.E.; English, B.C.; Larson, J.A. Investigating the impact of biomass quality on near-infrared models for switchgrass feedstocks. AIMS Bioeng. 2015, 3, 1-22. [CrossRef]

213. Gismatulina, Y.A.; Budaeva, V.V. Chemical composition of five Miscanthus sinensis harvests and nitric-acid cellulose therefrom. Ind. Crop. Prod. 2017, 109, 227-232. [CrossRef]

214. Yan, J.; Oyedeji, O.; Leal, J.H.; Donohoe, B.S.; Semelsberger, T.A.; Li, C.; Hoover, A.N.; Webb, E.; Bose, E.; Zeng, Y. Characterizing variability in lignocellulosic biomass-A review. ACS Sustain. Chem. Eng. 2020, 22, 8059-8085. [CrossRef]

215. Younis, M.; Alnouri, S.Y.; Abu Tarboush, B.J.; Ahmad, M.N. Renewable biofuel production from biomass: A review for biomass pelletization, characterization, and thermal conversion techniques. Int. J. Green Energy 2018, 15, 837-863. [CrossRef]

216. Acharjee, T.C.; Coronella, C.J.; Vasquez, V.R. Effect of thermal pretreatment on equilibrium moisture content of lignocellulosic biomass. Bioresour. Technol. 2011, 102, 4849-4854. [CrossRef] [PubMed]

217. Pereira, H. Cork: Biology, Production and Uses; Elsevier: Amsterdam, The Netherlands, 2011; ISBN 0080476864.

218. Pereira, H. Variability of the chemical composition of cork. BioResources 2013, 8, 2246-2256. [CrossRef]

219. Marques, A.V.; Pereira, H.; Meier, D.; Faix, O. Isolation and characterization of a guaiacyl lignin from saponified cork of Quercus suber L. Holzforsch. Int. J. Biol. Chem. Phys. Technol. Wood 1996, 50, 393-400.

220. Marques, A.V.; Pereira, H.; Meier, D.; Faix, O. Quantitative analysis of cork (Quercus suber L.) and milled cork lignin by FTIR spectroscopy, analytical pyrolysis, and total hydrolysis. Holzforsch. Int. J. Biol. Chem. Phys. Technol. Wood 1994, 48, 43-50.

221. Lourenço, A.; Pereira, H. Compositional variability of lignin in biomass. Lignin Trends Appl. InTech 2018, 65-98.

222. Kang, Q.; Appels, L.; Tan, T.; Dewil, R. Bioethanol from lignocellulosic biomass: Current findings determine research priorities. Sci. World J. 2014, 2014, 298153. [CrossRef]

223. López-González, D.; Fernandez-Lopez, M.; Valverde, J.L.; Sanchez-Silva, L. Thermogravimetric-mass spectrometric analysis on combustion of lignocellulosic biomass. Bioresour. Technol. 2013, 143, 562-574. [CrossRef]

224. Olivella, M.À.; Jové, P.; Şen, A.; Pereira, H.; Villaescusa, I.; Fiol, N. Sorption performance of Quercus cerris cork with polycyclic aromatic hydrocarbons and toxicity testing. BioResources 2011, 6, 3363-3375.

225. Şen, A.U.; Nobre, C.; Durão, L.; Miranda, I.; Pereira, H.; Gonçalves, M. Low-temperature biochars from cork-rich and phloem-rich wastes: Fuel, leaching, and methylene blue adsorption properties. Biomass Convers. Biorefinery 2020, 1-11. [CrossRef]

226. Telmo, C.; Lousada, J.; Moreira, N. Proximate analysis, backwards stepwise regression between gross calorific value, ultimate and chemical analysis of wood. Bioresour. Technol. 2010, 101, 3808-3815. [CrossRef] [PubMed]

227. Telmo, C.; Lousada, J. Heating values of wood pellets from different species. Biomass Bioenergy 2011, 35, 2634-2639. [CrossRef]

228. Almeida, G.; Brito, J.O.; Perré, P. Alterations in energy properties of eucalyptus wood and bark subjected to torrefaction: The potential of mass loss as a synthetic indicator. Bioresour. Technol. 2010, 101, 9778-9784. [CrossRef] [PubMed]

229. Arteaga-Pérez, L.E.; Segura, C.; Bustamante-García, V.; Cápiro, O.G.; Jiménez, R. Torrefaction of wood and bark from Eucalyptus globulus and Eucalyptus nitens: Focus on volatile evolution vs feasible temperatures. Energy 2015, 93, 1731-1741. [CrossRef]

230. Şensöz, S. Slow pyrolysis of wood barks from Pinus brutia Ten. and product compositions. Bioresour. Technol. 2003, 89, 307-311. [CrossRef]

231. Ingram, L.; Mohan, D.; Bricka, M.; Steele, P.; Strobel, D.; Crocker, D.; Mitchell, B.; Mohammad, J.; Cantrell, K.; Pittman, C.U., Jr. Pyrolysis of wood and bark in an auger reactor: Physical properties and chemical analysis of the produced bio-oils. Energy Fuels 2008, 22, 614-625. [CrossRef]

232. Mourant, D.; Lievens, C.; Gunawan, R.; Wang, Y.; Hu, X.; Wu, L.; Syed-Hassan, S.S.A.; Li, C.-Z. Effects of temperature on the yields and properties of bio-oil from the fast pyrolysis of mallee bark. Fuel 2013, 108, 400-408. [CrossRef] 
233. Cross, P.; Kulkarni, A.; Nam, H.; Adhikari, S.; Fasina, O. Bubbling fluidized bed gasification of short rotation Eucalyptus: Effect of harvesting age and bark. Biomass Bioenergy 2018, 110, 98-104. [CrossRef]

234. Gao, P.; Zhou, Y.; Meng, F.; Zhang, Y.; Liu, Z.; Zhang, W.; Xue, G. Preparation and characterization of hydrochar from waste eucalyptus bark by hydrothermal carbonization. Energy 2016, 97, 238-245. [CrossRef]

235. Pidtasang, B.; Sukkasi, S.; Pattiya, A. Effect of in-situ addition of alcohol on yields and properties of bio-oil derived from fast pyrolysis of eucalyptus bark. J. Anal. Appl. Pyrolysis 2016, 120, 82-93. [CrossRef]

236. Ren, X.; Meng, J.; Chang, J.; Kelley, S.S.; Jameel, H.; Park, S. Effect of blending ratio of loblolly pine wood and bark on the properties of pyrolysis bio-oils. Fuel Process. Technol. 2017, 167, 43-49. [CrossRef]

237. Salo, K.; Mojtahedi, W. Fate of alkali and trace metals in biomass gasification. Biomass Bioenergy 1998, 15, 263-267. [CrossRef]

238. Becker, A.; Scherer, V. A comparison of the torrefaction behavior of wood, miscanthus and palm kernel shells: Measurements on single particles with geometries of technical relevance. Fuel 2018, 224, 507-520. [CrossRef]

239. Wang, L.; Barta-Rajnai, E.; Skreiberg, Ø.; Khalil, R.; Czégény, Z.; Jakab, E.; Barta, Z.; Grønli, M. Effect of torrefaction on physiochemical characteristics and grindability of stem wood, stump and bark. Appl. Energy 2018, 227, 137-148. [CrossRef]

240. Anupam, K.; Swaroop, V.; Lal, P.S.; Bist, V. Turning Leucaena leucocephala bark to biochar for soil application via statistical modelling and optimization technique. Ecol. Eng. 2015, 82, 26-39. [CrossRef]

241. Sakthivel, R.; Ramesh, K.; Shameer, P.M.; Purnachandran, R. A complete analytical characterization of products obtained from pyrolysis of wood barks of Calophyllum inophyllum. Waste Biomass Valorization 2019, 10, 2319-2333. [CrossRef]

242. Moralı, U.; Şensöz, S. Pyrolysis of hornbeam shell (Carpinus betulus L.) in a fixed bed reactor: Characterization of bio-oil and bio-char. Fuel 2015, 150, 672-678. [CrossRef]

243. Sowmya Dhanalakshmi, C.; Madhu, P. Biofuel production of neem wood bark (Azadirachta indica) through flash pyrolysis in a fluidized bed reactor and its chromatographic characterization. Energy Sources Part A Recover. Util. Environ. Eff. 2019, 43, 1-16. [CrossRef]

244. Pidtasang, B.; Udomsap, P.; Sukkasi, S.; Chollacoop, N.; Pattiya, A. Influence of alcohol addition on properties of bio-oil produced from fast pyrolysis of eucalyptus bark in a free-fall reactor. J. Ind. Eng. Chem. 2013, 19, 1851-1857. [CrossRef]

245. Li, D.; Berruti, F.; Briens, C. Autothermal fast pyrolysis of birch bark with partial oxidation in a fluidized bed reactor. Fuel 2014, 121, 27-38. [CrossRef]

246. Pan, S.; Pu, Y.; Foston, M.; Ragauskas, A.J. Compositional characterization and pyrolysis of loblolly pine and Douglas-fir bark. BioEnergy Res. 2013, 6, 24-34. [CrossRef]

247. Sharma, A.; Pareek, V.; Zhang, D. Biomass pyrolysis-A review of modelling, process parameters and catalytic studies. Renew. Sustain. Energy Rev. 2015, 50, 1081-1096. [CrossRef]

248. Silva, S.P.; Sabino, M.A.; Fernandes, E.M.; Correlo, V.M.; Boesel, L.F.; Reis, R.L. Cork: Properties, capabilities and applications. Int. Mater. Rev. 2005, 50, 345-365. [CrossRef]

249. Jiang, S.; Nguyen, T.A.H.; Rudolph, V.; Yang, H.; Zhang, D.; Ok, Y.S.; Huang, L. Characterization of hard-and softwood biochars pyrolyzed at high temperature. Environ. Geochem. Health 2017, 39, 403-415. [CrossRef]

250. Tsoumis, G. Science and Technology of Wood: Structure, Properties, Utilization; Van Nostrand Reinhold: New York, NY, USA, 1991; Volume 115.

251. Hagner, M.; Tiilikkala, K.; Lindqvist, I.; Niemelä, K.; Wikberg, H.; Källi, A.; Rasa, K. Performance of liquids from slow pyrolysis and hydrothermal carbonization in plant protection. Waste Biomass Valorization 2020, 11, 1005-1016. [CrossRef] 